\title{
A unique small-scale microclimatic gradient in a temperate karst harbours exceptionally high diversity of soil Collembola
}

\author{
Natália Raschmanová ${ }^{1^{*}}$, Dana Miklisová ${ }^{2}$, and Lubomír Kováč ${ }^{1}$ \\ ${ }^{1}$ Institute of Biology and Ecology, Faculty of Science, P. J. Šafárik University, Šrobárova 2, 04154 Košice, Slovakia \\ ${ }^{2}$ Institute of Parasitology, Slovak Academy of Sciences, Hlinkova 3, 04001 Košice, Slovakia
}

\begin{abstract}
The collapse doline of the Silická l'adnica Ice Cave, $351 \mathrm{~m}^{2}$ in area, is a unique phenomenon, a steep microclimate gradient in a low-altitude temperate karst in the Western Carpathian Mts, Slovakia, with a remarkable temperature decrease from the edge of karst plateau towards the doline bottom, which harbours perennial ice deposits. Collembola communities were studied in detail at seven sites along the $117.5 \mathrm{~m}$ long gradient slope during 20052007. An exceptionally high species richness of soil Collembola was observed, 129 species, which is about $91 \%$ of the total species richness generated by Chao1/ACE estimator. Species richness positively correlated with soil temperature at the sites. Among the occupants of the karst doline, 10 were Carpathian or Western-Carpathian endemics, and 21 were coldadapted (psychrophilic) species with montane or boreo-montane disjunctive distribution. A high number and high abundance of endemic species occurred in the middle zone of the gradient slope. The study further showed that cold and wet karst scree slopes in the transition zone between surface habitats and caves may represent borderline habitats for obligate subterranean species. Communities at cold sites had much steeper rank-dominance curves compared to upper mesophilous and thermophilous sites, thereby documenting the harsh character of this environment. Our results suggest that small-scale microclimatic gradients in a low altitude karst in a temperate zone may serve as a reservoir (source) of exceptional soil fauna diversity, providing important climatic microrefugia for endemic and relict taxa. Karst landforms in the temperate zone with strong climatic inversions may harbour high biodiversity and thus should be central in biodiversity conservation programs.
\end{abstract}

Keywords: microrefugium, microclimate, ecotone, relict species, species vulnerability

Received 26 March 2018; Revised 22 May 2018; Accepted 20 June 2018

Citation: Raschmanová N., Miklisová D. and Kováč L'., 2018. A unique small-scale microclimatic gradient in a temperate karst harbours exceptionally high diversity of soil Collembola. International Journal of Speleology, 47 (2), 247-262. Tampa, FL (USA) ISSN 0392-6672 https://doi.org/10.5038/1827-806X.47.2.2194

\section{INTRODUCTION}

The diversity of biota can be very high in some ecosystems of the temperate zone. The remarkable biodiversity of mountain regions is considered to be the result of a large variety of natural conditions, the fragmentation of the mountain ridges, diverse geological bedrock and landscape relief and the independent evolution of fauna and flora during historical periods (Köck et al., 2014). This is also well documented for the Carpathians Mountains, which are considered to be a clear hotspot of European diversity for many groups of organisms (Mráz \& Ronikier, 2016). Studies focused on species diversity of soil arthropods have indicated high species diversity in heterogeneous environments (e.g., Brose et al., 2003; Tews et al., 2004). Surface karst landforms, the dominant and significant elements of karst regions, are characterized by heterogenous geomorphology, including deep valleys, gorges, sinkholes and collapse dolines that are considered "habitat islands" associated with microclimate and vegetation gradients, which determine high local diversity and endemism of biota (e.g., Bardgett et al., 2005; Raschmanová et al., 2008; Villisics et al., 2011; Bátori et al., 2011; 2012; 2017). The topography, soil microclimate, edaphic factors and structure of the vegetation cover of karst landforms play a crucial role in determining the diversity and abundance patterns of the soil Collembola at sites ruled by the climatic inversion (Raschmanová et al., 2008; 2013; 2016). Due to inverted microclimatic conditions, often with pronounced gradients, deep karst dolines may serve as climatic microrefugia (Rull, 2009) for a wider spectrum of relicts (Bátori et al., 2014), such as cold-adapted (psychrophilic) species with montane, 
disjunctive boreo-montane and arctic-alpine distribution ranges. Generally, these habitats are considered buffered environments for psychrophilic forms under ongoing global warming in terms of their ability to sustain a more or less stable microclimate (Dobrowski, 2010; Raschmanová et al., 2013; Bátori et al., 2014; 2017), but in the same way they may also become endangered habitats, given the potential loss of their refugial features with changing conditions on the surface (Wynne et al., 2014). Thus, preservation of these karst landforms and their sensitive soil biota should be a part of proper conservation programs and biodiversity management of natural habitats (Breg, 2007; Raschmanová et al., 2015). Moreover, it was found that heterogeneous environments of temperature and vegetation gradients in karst landforms may be associated with cryptic diversity (Raschmanová et al., 2017). Generally, populations of species with narrow distribution along the gradient slopes are highly vulnerable, and their extinction may lead to the loss of local functional diversity in these ecosystems.

The Silická ladnica Ice Cave, listed among UNESCO World Heritage Sites, is a unique phenomenon characterized by perennial ice accumulations and a pronounced microclimatic gradient in a collapse doline at the front of the cave. Our previous papers based on one-year study focusing on the doline showed relatively high local species diversity and distinct communities of soil Collembola at individual sites of the doline slope (Raschmanová et al., 2013; 2015). Several recent studies have stressed the importance of cave entrances as a unique and complex ecotone that may harbour high species diversity and endemism of terrestrial invertebrates (Wynne et al., 2014; Prous et al., 2015; Yao et al., 2016).

In the present study we analyzed a larger dataset from the Silická ladnica Ice Cave originating over a 3-year period. We hypothesized that karst landscape gradients serve as islands of exceptional diversity of soil fauna and provide important microrefugia for endemic and relict taxa. The study aimed to answer the following questions: (1) what is the total diversity and dominance pattern of species in collembolan communities at individual sites along the microclimatic gradient in the collapse doline of the Silická ladnica Ice Cave, and (2) what is the presumed role of natural small-scale microclimatic gradients in a low-altitude temperate karst in terms of a potential microrefugium and source of local species diversity of the soil fauna. Furthemore, data on local species richness of the unique climatic gradients in karst areas may provide a focus for legislation in term of conservation of rare and vulnerable species, as important components of global biodiversity.

\section{MATERIALS AND METHODS}

\section{Site description}

The Silická ladnica Ice Cave (48³2'58.9"N and $\left.20^{\circ} 30^{\prime} 13.9^{\prime \prime} \mathrm{E}\right)$ is located in the Slovak and Aggtelek Karst, Western Carpathian Mts, Slovakia (Fig. 1A). The region is characterized by a mid-latitude karst landscape with a series of karst plateaus at elevations between 400 and $700 \mathrm{~m}$ a.s.1., with decreasing elevation from the north to the south, separated by $100-300 \mathrm{~m}$ deep canyons and valleys. Dolines (sinkholes), blind valleys and karrens belong among the typical landform features in this region. Mean annual temperature in the area ranges from +5.7 to $+8.5^{\circ} \mathrm{C}$ and annual average precipitation from 630 to $990 \mathrm{~mm}$ (Rozložník et al., 1994; Hofierka et al., 2008).

The Silická ladnica Ice Cave was formed in Middle Triassic Wetterstein limestones of Silica Nappe. The entrance zone of the cave is a steeply inclined spacious cavity with a large opening to the surface (corrosivecollapsed abyss, light hole). In this part, the cave contains perennial ice decorations and permanent floor ice in form of a little glacier. The cave entrance lies at an elevation of $470 \mathrm{~m}$, facing north in a leafy forest. The upper edge of the collapse doline-like depression extends to a height of $503 \mathrm{~m}$ a.s.1. This site is thus the lowest-lying perennial ice cave below the latitude of 50 degrees north in the temperate climatic zone. The volume of ice accumulations in the cave ranges between 213 and $340 \mathrm{~m}^{3}$ (Roda et al., 1974). The permanent glaciation of the cave entrance zone is a relatively recent phenomenon induced by collapse of the cave roof dated back 2000 years (Bella \& Zelinka, 2018).

Seven sites were selected along the scree slope representing a natural temperature gradient on a $117.5 \mathrm{~m}$ transect line from the bottom of cave mouth to the upper part of the doline, (a surface area of 351 $\mathrm{m}^{2}$ ). Sites were situated on a scree slope of $5-35^{\circ}$ at an elevation of 451-500 $\mathrm{m}$ a.s.1. facing south and southwest. For a detailed location of research sites, see Figs 1B-C. Site (1) was $7 \mathrm{~m}$ from the edge of permanent floor ice, a specific habitat near the cave entrance with primary soil on stony debris. Site (1) and (2) had pioneer vegetation of mosses and liverworts, shallow soil 3-4 cm deep and soil type lithosol. Site (3) had sparse pioneer vegetation of mosses, liverworts and herbal cover with Urtica sp., soil depth $10 \mathrm{~cm}$ at maximum, rendzina soil type. Site (4) was situated in a microdepression on a moderate slope with dense herbal cover and well developed $15 \mathrm{~cm}$ deep rendzina soil. Site (5) was hornbeam maple wood near a rock wall on a very moderate slope with dense herbal cover and shallow lithosol. Site (6) was young hornbeam wood on a steep slope with rendzina soil. Both sites $(5,6)$ had stony shallow soil, $5 \mathrm{~cm}$ deep. The last site (7) was cornel-hornbeam wood on the edge of the karst plateau with $10-20 \mathrm{~cm}$ thick soil profile, cambisol. The vegetational associations of sites were characterized by Petrášová \& Šuvada (2008). At the bottom of doline (sites 1-3) the soil was frozen during winter and early spring and covered by snow in variable thickness and duration.

The sampling design, specifically the number of samples collected at the sites, was applied to prevent potential destruction of the unique and fragile habitats in the collapse doline. A total of 5 replicate soil samples were taken from each site in spring and autumn during the period 2005-2007 (18 May and 

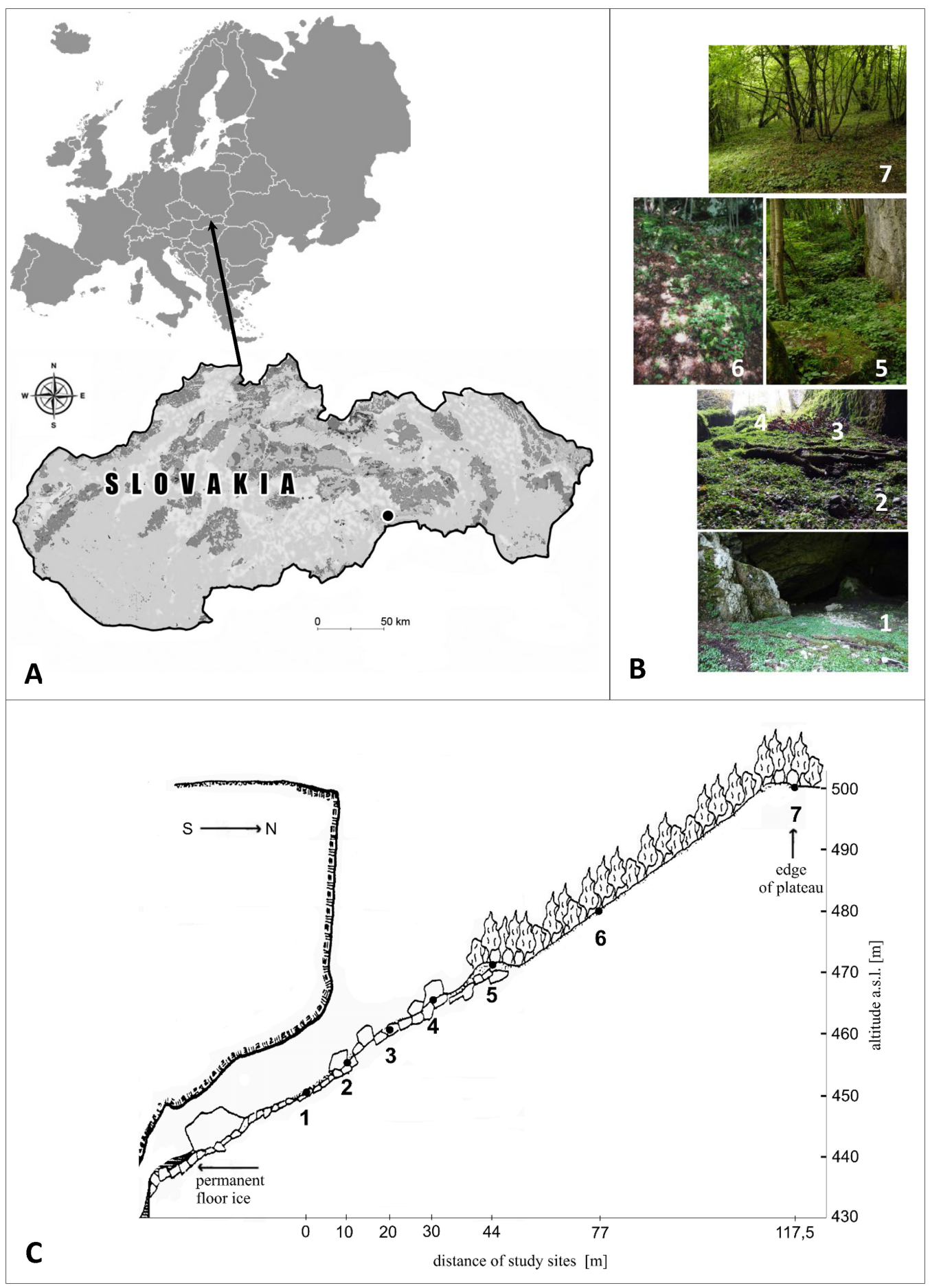

Fig. 1. A) Black circle - the collapse doline of the Silická ladnica Ice Cave; B) Collecting sites in the collapse doline; C) Location of research sites (black circles) on scree slope in the collapse doline (according to Raschmanová et al., 2013) (for site numbers see chapter Methods).

13 November 2005, 18 May and 25 October 2006, 1 May and 6 October 2007), i.e., 210 samples altogether. The samples represented soil cores $10 \mathrm{~cm}$ in diameter to a maximum depth of $8 \mathrm{~cm}$ (depending on the soil thickness), including litter layer. Soil microarthropods were extracted in a modified high-gradient apparatus (Crossley \& Blair, 1991) for 7 days. Collembola were identified to the species level using identification keys, specifically Weiner (1981); Pomorski (1998); Fjellberg (1998, 2007); Bretfeld (1999); Potapov (2001); Smolis \& Skarzynski (2003); Thibaud et al. (2004); Dunger \& Schlitt (2011); and others. This literature was also used as a source of data on geographic distribution and ecology of individual species. Collembola recorded at sites were classified after Culver \& Pipan (2014) into edaphobionts as obligate soil-dwellers, troglobionts as obligate cavedwellers and generalist species with occurence in both soil and hypogean environments. Collembola specimens are deposited in collection of P. J. Šafárik University, Košice, Slovakia.

\section{Climatic, soil-microclimatic, and soil-chemical data}

Climate dynamics recorded by the nearest meteorological station in the village of Silica during the sampling period are provided in Fig. 2. The basic characteristics of the sites are given in Table 1. Soil temperature at the sites was measured by dataloggers (iButton DS1921G) continually every 4 hours from September 2006 to October 2007 at a depth of 


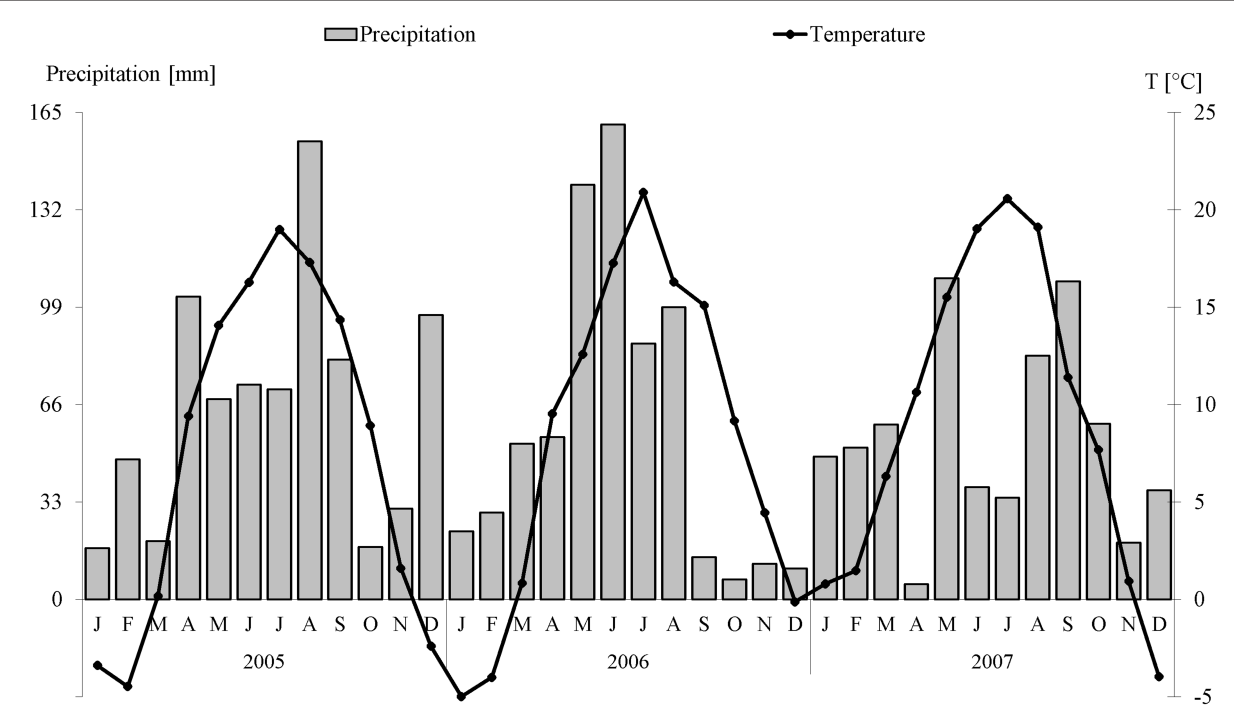

Fig. 2. Monthly rainfall and air temperature data from the nearest meteorological station in Silica (2005-2007).

$3 \mathrm{~cm}$ and calculated as daily averages; the mean, minimum and maximum values $\left(\mathrm{T}_{\text {mean }}, \mathrm{T}_{\min }\right.$ and $\left.\mathrm{T}_{\max }\right)$ were calculated for each site. Three soil samples were taken for gravimetric soil moisture from each site in October 2007. Further details on the microclimatic gradient at the collapse doline of the Silická Padnica Ice Cave are provided by Raschmanová et al. (2013). Soil $\mathrm{pH}$ was measured potentiometrically using a glass electrode and a reference calomel electrode as active $\mathrm{pH}$ in water $\left(\mathrm{pH}_{\mathrm{H} 2 \mathrm{O}}\right)$. Soil organic carbon content (C) and total $\mathrm{N}$ were measured according to Králová et al. (1991).

\section{Community data analyses}

Abundance (A), species richness (S), the Shannon diversity index $\left(\mathrm{H}^{-}\right)$, the Pielou index of evenness $\left(\mathrm{J}^{\prime}\right)$ and total species richness estimators for each site were calculated from the period $2005-2007$ as principal community parameters. Relationships between environmental factors $\left(\mathrm{T}_{\text {mean }}, \mathrm{T}_{\min }, \mathrm{T}_{\max }, \mathrm{W}\right)$ and average community parameters $\left(\mathrm{A}, \mathrm{S}, \mathrm{H}^{\prime}, \mathrm{J}^{\prime}\right)$ at every site were evaluated by the nonparametric Spearman's correlation coefficient at a significance level of $\mathrm{P}<0.05$. Furthermore, the Spearman coefficient was used to evaluate the relation between the abundance of cold-adapted species and site along the gradient. Differences in soil temperature, moisture and Collembola abundance between sites were tested by nonparametric Kruskal-Wallis ANOVA, with post hoc multiple comparing (Statistica for Windows version 12).

To examine general trends in the Collembola dominance structure at each site, dominance curves were plotted for every site and for the three-year period. Species were ranked by dominance, and the percentage of the total number of individuals belonging to each species was plotted to base 10 logarithmic scale against species rank.

Theoretical species richness was estimated globally and for each site by diversity estimators from samplebased abundance data. By default, the biasedcorrected form of Chao1 along with log-linear 95\% confidence intervals is used. For those datasets with a coefficient of variation of the abundance distribution greater than 0.5 , the larger from the Chao 1 classic and ACE richness estimators is recommended (Chao, 1987; Chao et al., 2005; Colwell et al., 2012). Furthermore, the data were analysed using rarefaction procedures that are specifically designed to avoid the potential bias generated by uneven sampling. The estimation

Table 1. Vegetation associations, soil microclimatic and chemical characteristics at sites in the collapse doline.

\begin{tabular}{|c|c|c|c|c|c|c|c|}
\hline & 1 & 2 & 3 & 4 & 5 & 6 & 7 \\
\hline $\begin{array}{l}\text { Vegetation } \\
\text { associations }\end{array}$ & $\begin{array}{c}\text { ass. Cardamino- } \\
\text { Chrysosplenietum } \\
\text { alternifolii Maas } \\
1959\end{array}$ & $\begin{array}{c}\text { ass. Cardamino- } \\
\text { Chrysosplenietum } \\
\text { alternifolii Maas } \\
1959\end{array}$ & $\begin{array}{c}\text { ass. Cardamino- } \\
\text { Chrysosplenietum } \\
\text { alternifolii Maas } \\
1959\end{array}$ & \begin{tabular}{c|} 
ass. Cardamino- \\
Chrysosplenietum \\
alternifolii Maas \\
1959, Lunario- \\
Aceretum \\
Grüneberg \& \\
Schlüt 1957
\end{tabular} & $\begin{array}{l}\text { ass. Lunario- } \\
\quad \text { Aceretum } \\
\text { Grüneberg \& } \\
\text { Schlüt } 1957\end{array}$ & $\begin{array}{c}\text { ass. } \\
\text { Waldsteinio- } \\
\text { Carpinetum } \\
\text { (Jakucs \& } \\
\text { Jurko 1967) } \\
\text { Soó 1971 }\end{array}$ & $\begin{array}{c}\text { ass. } \\
\text { Waldsteinio- } \\
\text { Carpinetum } \\
\text { (Jakucs \& } \\
\text { Jurko 1967) } \\
\text { Soó } 1971\end{array}$ \\
\hline $\mathrm{T}_{\text {mean }}\left[{ }^{\circ} \mathrm{C}\right]$ & $1.7 \pm 2.16 \mathrm{a}$ & $2.7 \pm 2.43 \mathrm{~b}$ & $4.1 \pm 3.09 c$ & $5.4 \pm 4.0 \mathrm{~d}$ & $7.2 \pm 5.31 \mathrm{e}$ & $8.2 \pm 4.92 f$ & $8.3 \pm 4.81 \mathrm{f}$ \\
\hline $\mathrm{T}_{\min }\left[{ }^{\circ} \mathrm{C}\right]$ & -2.6 & -0.5 & -0.5 & -0.3 & -1.0 & -0.1 & 0.1 \\
\hline $\mathrm{T}_{\max }\left[{ }^{\circ} \mathrm{C}\right]$ & 5.0 & 6.3 & 8.5 & 11.0 & 16.3 & 17.5 & 17.5 \\
\hline W [\%] & $53.65 \pm 3.76 a b$ & $63.72 \pm 3.06 a$ & $64.23 \pm 2.39 a$ & $47.64 \pm 5.60 \mathrm{ab}$ & $36.74 \pm 4.19 a b$ & $33.17 \pm 5.14 \mathrm{ab}$ & $28.04 \pm 3.75 b$ \\
\hline $\mathrm{pH}_{\mathrm{H} 2 \mathrm{O}}$ & 7.3 & 6.9 & 7 & 7 & 7 & 6.5 & 6 \\
\hline $\mathrm{C} / \mathrm{N}$ & 28.1 & 30.9 & 22.5 & 21.3 & 26.3 & 24.3 & 21 \\
\hline
\end{tabular}

$\mathrm{T}_{\text {mean }}$ - mean soil temperature (from daily averages, September 2006-October 2007) and standard deviation, $\mathrm{T}_{\min }-$ daily minimum soil temperature, $\mathrm{T}_{\max }$ - daily maximum soil temperature, $\mathrm{W}$ - average soil moisture and standard deviation (October 2007), $\mathrm{pH} / \mathrm{H}_{2} \mathrm{O}, \mathrm{C} / \mathrm{N}$ soil ratio (June 2009), (for site numbers see chapter Methods). Significant differences between sites (Kruskal-Wallis ANOVA with post hoc multiple comparing) are indicated by different lowercase letters for $\mathrm{T}_{\text {mean }}\left[{ }^{\circ} \mathrm{C}\right]$ and $\mathrm{W}[\%]$ separately. 
of species richness, rarefaction and extrapolation curves were calculated by the Estimates software (Colwell, 2013).

\section{RESULTS}

\section{Climatic, soil-microclimatic, and soil-chemical data}

Based on the climatic data recorded from the nearest meteorological station, the annual air temperature and precipitation means for the sequence of years 2005-2007 were 7.6, 8.1, and $9.1^{\circ} \mathrm{C}$, and 65, 57.6, and $54.3 \mathrm{~mm}$, respectively (Fig. 2). Relatively high monthly precipitation was recorded in spring and summer of 2005 and 2006, and in spring and autumn of 2007 . The vegetation, soil microclimatic and chemical characteristics documented notable differences at collecting sites along the slope (Table 1). The soil temperature (September 2006 - October 2007) at sites ranged as follows: $\mathrm{T}_{\text {mean }}, 1.7-8.3^{\circ} \mathrm{C}, \mathrm{T}_{\min },-2.6-$ $0.1^{\circ} \mathrm{C}$, and $\mathrm{T}_{\max }, 5.0-17.5^{\circ} \mathrm{C} . \mathrm{T}_{\text {mean }}$ was significantly different between sites at $\mathrm{P}<0.05$, while sites 6 and 7 represented a homogenous group. Soil moisture ranged considerably between $28.04 \%$ (site 7) and $64.23 \%$ (site 3 ); its value at site 7 was significantly lower than at sites 2 and 3, while other differences between sites in this parameter were statistically not significant. The highest soil $\mathrm{pH}$ was near the permanent ice (1), and identical $\mathrm{pH}$ values were found at sites $3-5$ in the middle part of the transect. The cold sites $(1,2)$ had a higher $\mathrm{C} / \mathrm{N}$ ratio compared to others, followed by two wood sites $(5,6)$; lower values of the parameter were recorded at sites with herbal cover $(3,4)$, and the lowest in the thermophilous wood on the edge of karst plateau (7) (Table 1).

\section{Community data}

Average values of abundances (A), species richness (S) and its estimator (Chao1 or ACE) and the diversity indices $\left(\mathrm{H}^{\prime}, \mathrm{J}\right)$ of communities at the sites are shown in Table 2. The mean abundance of the assemblages at the seven sites ranged from 9,151 to 38,209 individuals $\mathrm{m}^{-2}$. A clearly higher mean abundance was observed near the permanent floor ice (site 1) compared to other sites. Considerably high numbers of the dominant species Ceratophysella sigillata and cold-adapted cryptic species of the genus Folsomia (Raschmanová et al., 2017) in the samples taken at the coldest site (1) in spring led to an extremely high standard deviation of mean abundance. Relatively high values of the abundance were detected at unforested sites (2), in the slope microdepression with herbal cover (4) and in young thermophilous wood (6), followed by thermohilous wood on the plateau (7) and cold site (3) with more or less similar values. The lowest mean abundance was observed in the hornbeam-maple wood on the modest slope (5), being significantly lower than at sites 2 and 4; other differences were statistically not confirmed.

Table 2. Community parameters of Collembola at sites in the collapse doline over three years (2005-2007).

\begin{tabular}{|c|c|c|c|c|c|c|c|c|}
\hline & 1 & 2 & 3 & 4 & 5 & 6 & 7 & Total \\
\hline Samples & 30 & 30 & 30 & 30 & 30 & 30 & 30 & 210 \\
\hline A [ind. $\mathrm{m}^{-2}$ ] & $38209 a b$ & $26807 a$ & $14718 \mathrm{ab}$ & $20038 a$ & $9151 b$ & $173421 \mathrm{ab}$ & $159871 \mathrm{ab}$ & - \\
\hline St. dev. & \pm 56629 & \pm 23645 & \pm 10327 & \pm 16025 & \pm 4400 & \pm 12404 & \pm 13597 & - \\
\hline $\mathrm{H}^{-}$ & 0.79 & 1.77 & 2.59 & 2.84 & 3.02 & 2.64 & 2.42 & - \\
\hline $\mathrm{J}^{-}$ & 0.22 & 0.47 & 0.65 & 0.69 & 0.73 & 0.63 & 0.60 & - \\
\hline $\mathrm{S}$ & 35 & 44 & 52 & 61 & 61 & 64 & 57 & 129 \\
\hline CI for $\mathrm{S}$ & $28.2-41.8$ & $38.1-50.0$ & 46.1-57.9 & $54.6-67.4$ & $52.5-69.6$ & $56.1-71.9$ & $49.3-64.7$ & $121.1-136.9$ \\
\hline Chao1 / *ACE & 55 & $53^{*}$ & 57 & 67 & 77 & 77 & 66 & 143 \\
\hline CI for Chao1 & $40.2-107.9$ & - & $53.0-72.7$ & $62.5-82.0$ & $65.6-118.7$ & 67.7-109.6 & $59.4-88.6$ & $133.8-167.1$ \\
\hline $\mathrm{S}_{\mathrm{E}}[\%]$ & 64.2 & 83.8 & 92.0 & 91.6 & 78.9 & 83.1 & 86.8 & 90.5 \\
\hline
\end{tabular}

A - mean abundance, St. dev. - standard deviation of abundance mean, $\mathrm{S}$ - species richness, $\mathrm{H}^{-}-\mathrm{Shannon}$ diversity index, $\mathrm{J}^{-}-\mathrm{Pielou}$ index of evenness, Chao 1 - richness estimator for individual-based abundance data, ${ }^{*} \mathrm{ACE}-$ abundance coverage-based estimator of species richness (only for site 2 computed), CI - 95\% confidence intervals with lower and upper bounds; $\mathrm{S}_{\mathrm{E}}-\mathrm{S}$ expressed as \% of richness estimator, (for site numbers see chapter Methods). Significant differences between sites (Kruskal-Wallis ANOVA with post hoc multiple comparing) are indicated by different lowercase letters for A [ind. $\mathrm{m}^{-2}$ ]

A total of 33,500 individuals of Collembola belonging to 129 species were collected at the sites during the sampling period (Appendix). Juvenile forms of the families Entomobryidae and Tomoceridae were not considered as separate species/taxa. High diversity indices were observed at sites 4-6, somewhat lower at unforested site (3) and at the top of plateau (7) (Table 2). The lowest values were recorded at cold sites with lithosol and a very shallow soil layer $(1,2)$ that hosted communities with highly abundant species $C$. sigillata, Folsomia sp., Protaphorura aurantiaca and P. armata. The total species richness of Collembola at sites along the gradient (1-7) positively correlated with the mean and maximum soil temperatures: $\mathrm{T}_{\text {mean }}(\mathrm{r}=0.77 ; \mathrm{p}<0.05)$ and $\mathrm{T}_{\max }(\mathrm{r}=0.88 ; \mathrm{p}<0.01)$. There were no significant correlations between environmental factors $\left(\mathrm{T}_{\text {mean }}, \mathrm{T}_{\min }, \mathrm{T}_{\max }, \mathrm{W}\right)$ and other community parameters $\left(\mathrm{A}, \mathrm{H}^{\prime}, \mathrm{J}^{\prime}\right)$.

Rank-dominance curves were much steeper in communities at cold sites $(1,2)$ than those at sites in the middle and upper part of the slope as a result of the higher dominance of a few species and lower species numbers at cold sites (Fig. 3).

The rarefaction curves created plotting the number of individuals against the number of species for individual sites did not approach a horizontal asymptote (Figs. 4A-B), indicating that during the study total species richness was underestimated in all cases. To get a more precise picture, species richness estimators (ACE for site 2, Chao1 for the rest) and 95\% confidence intervals (CI) for species richness estimators were generated for each site 


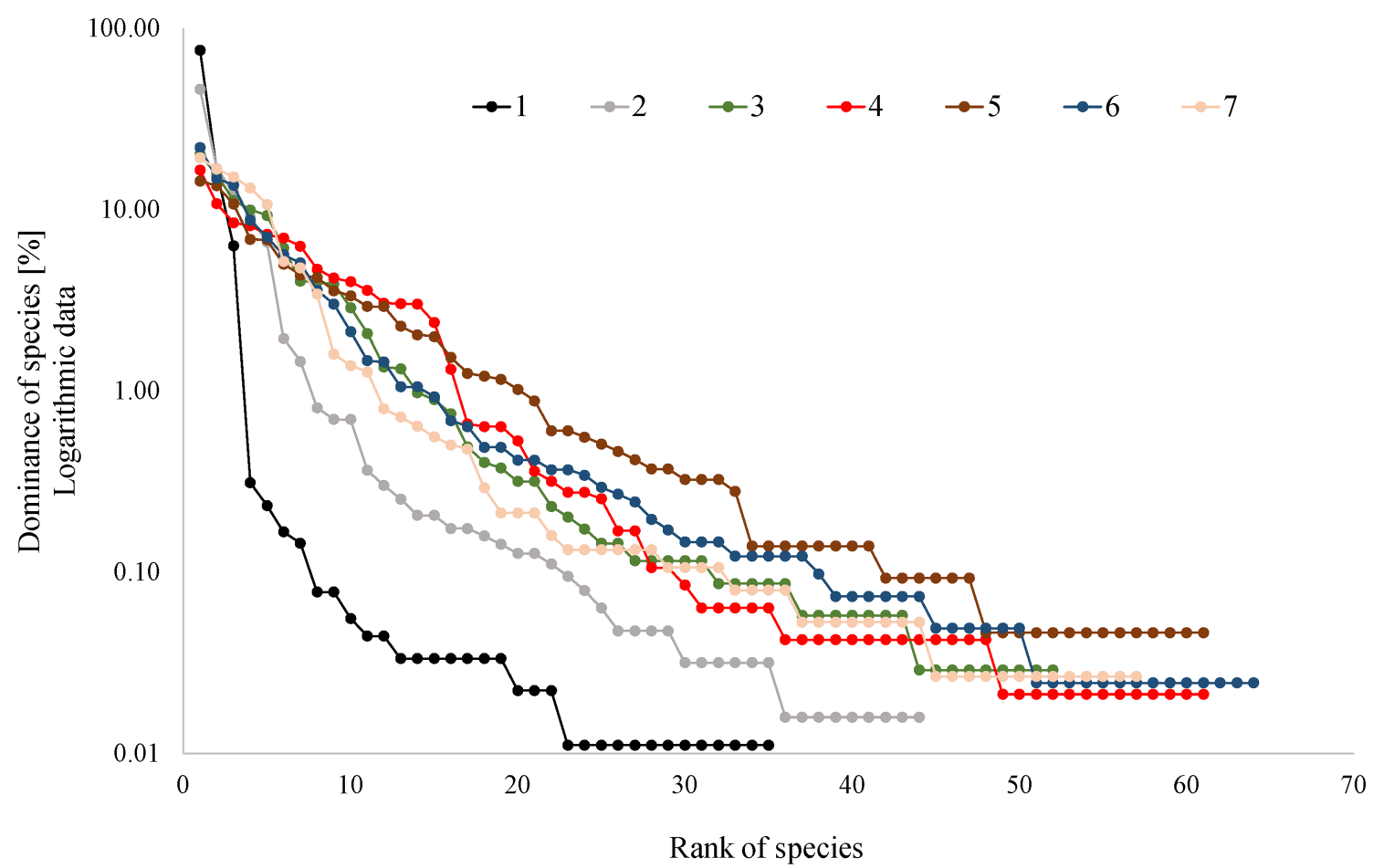

Fig. 3. Rank dominance curves of collembolan species at seven sites over a three-year period (2005-2007) (for site numbers see chapter Methods).

(Table 2). A total of 143 species with CI 133.8167.1 was found for all sites along the gradient, indicating that about $90.5 \%$ of the species richness was recorded in this study. The greatest difference between observed (S) and estimated richness was at cold site (1): 35 (CI 28.2-41.8) and 55 (CI 40.2107.9) species, respectively; thus, only $64.2 \%$ of the estimated species richness was recorded in this case. On the other hand, a slight difference between both parameters was observed at unforested site (3), i.e., 52 and 57 species, with $92.0 \%$ of the estimated species richness. Sites (5) and (6) had a high estimated species richness, both with 77 species, followed by the site in the slope microdepression (4) and the thermophilous wood on the plateau (7), with 67 and 66 species, respectively.

The majority of species recorded have large distribution ranges: cosmopolitan, Holarctic, Palearctic, and European distribution. Altogether, 21 were montane species, 10 of which were Carpathian/ Western Carpathian endemics (Appendix). Two Western Carpathian endemics of subterranean fauna, Megalothorax carpaticus and Pygmarrhopalites aggtelekiensis, were recorded at cold site (2). The proportion of cold-adapted species to overall species richness at sites and their abundance to overall community abundance are provided in Figs. 5A-B. The highest richness of these species was recorded in the middle $(4)$ and upper zones $(5,6)$ of the gradient (9-11 species), being lower at other sites along the gradient slope (6-7 species). Their proportion in abundance provided a considerably different picture: abundance decreased with temperature increase at slope sites $(-0.93 ; \mathrm{p}<0.01)$. The highest abundance of psychrophilic species was found at the coldest site (1) due to the occurrence of the very
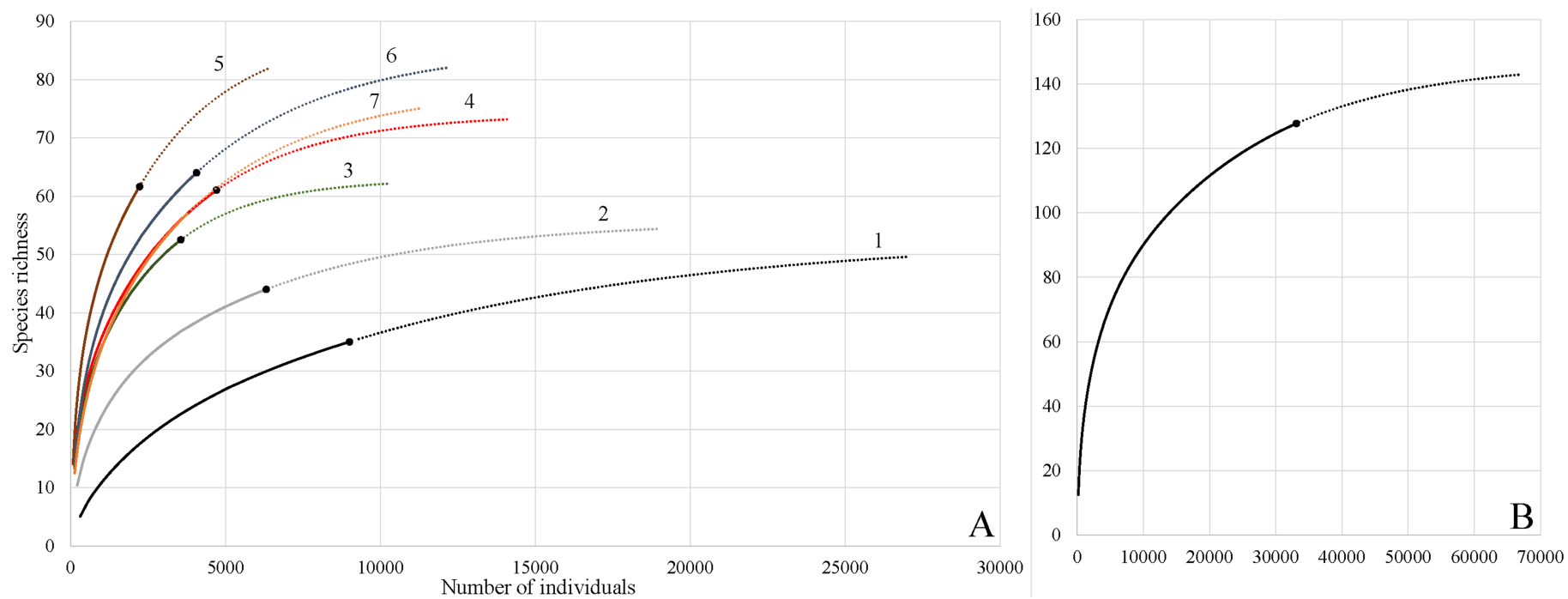

Fig. 4. A) Rarefaction (solid line) and extrapolation (dotted line) of soil collembolan species richness at seven sites in the collapse doline over a three-year period (2005-2007); B) Rarefaction (solid line) and extrapolation (dotted line) of total collembolan species richness over a three-year period. Reference samples are indicated by solid circles (for site numbers see chapter Methods). 
abundant species $C$. sigillata. On the other hand, a very low abundance of these forms was observed at the thermophilous forest sites (5-7). A high number and dominance of Carpathian/Western Carpathian endemics was recorded in the middle zone of the gradient (4), whilst their lower number and dominance were found at thermophilous (5-7) and cold sites (2-3).

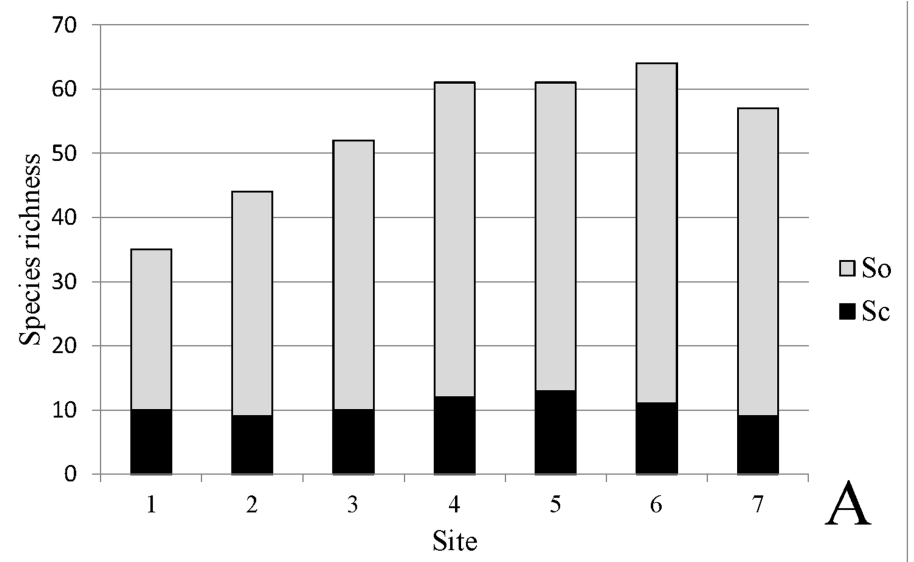

Overall, we found 102 species of edaphobionts (increasing trend in numbers of species from the doline bottom to the plateau edge), 1 troglobiotic species and 24 generalist species. Two generalists were more abundant, namely Protaphorura armata and Plutomurus carpaticus, distributed at cold sites of the slope (1-4). The only troglobiont with marked troglomorphic characters was Pygmarrhopalites aggtelekiensis.

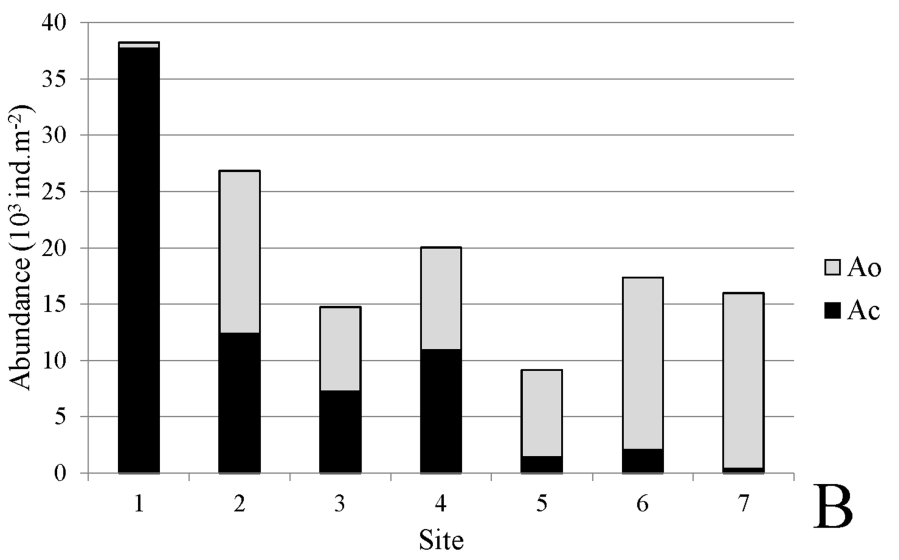

Fig. 5. A) The share of cold-adapted/psychrophilic to other species at sites over a three-year period (2005-2007) (for site numbers see chapter Methods), Sc - species richness of cold-adapted species, So - species richness of other species; B) Average abundances of cold-adapted species and others, Ac - mean abundances of cold-adapted species, Ao - mean abundances of others.

\section{DISCUSSION}

\section{Diversity and abundance patterns along microclimatic gradient}

Biodiversity can be quantified in many ways; however, species richness and single-index diversity (e.g., Shannon-Wiener) remain the most commonly used metric parameters to cover the alpha diversity of communities (Fleishman et al., 2006). In the present study species richness showed a strong positive correlation with soil temperature, as high species richness and also diversity indices were observed at sites in the middle and upper part of the scree slope. In contrast, low species richness and diversity indices were recorded at cold sites with a very shallow lithosol at the bottom of doline.

Species richness estimators and rarefaction curves are reliable and meaningful techniques for calculating the overall number of species used as an essential objective for conservation and management of natural habitats (Schneider \& Culver, 2004; Budlle et al., 2005). Such attempts are very useful, especially for studies covering small areas, where more intensive sampling could cause habitat destruction. We found that the upper four sites of the doline slope had greater estimated species richness compared with the rest of the sites, as indicated by estimators and rarefaction curves of cumulative species richness. Saturation curves for individual sites did not reach an asymptote, indicating that the species inventory during the three years was still incomplete, ranging from 64 to $92 \%$. The coldest site in the gradient had the lowest proportion of detected species and was associated with continual addition of species with random occurrence during the sampling period.

The rank-dominance curves documented the differences in the structure of Collembola communities between sites of the slope. Curves of the two cold sites were much steeper than the rest of the sites, indicating lower diversity and high dominance of a few species. The dominance structure at cold sites was thus unbalanced, showing low evenness due to the mass occurrence of the cold-adapted species $C$. sigillata and the cryptic species Folsomia sp. and $P$. armata. In contrast, communities at other sites of the gradient had more evenly spaced dominance among species. Moreover, the low standard deviations of mean abundances documented the even distribution of species abundance in soil samples, thus reflecting habitat homogeneity.

The highest abundances of Collembola and the lowest species richness and diversity indices were recorded at the two coldest sites of the inversion slope, thus reflecting a general trend of diversity and abundance of soil biota that is inversely related to latitude (e.g., Petersen \& Luxton, 1982; Giller, 1996; Gaston, 2000; Bardgett et al., 2005). Collembola colonizing habitats with an extremely cold climate, such as polar tundra regions, have generally the higher abundances (145,000-245,000 ind. $\left.\mathrm{m}^{-2}\right)$ and lower species richness (13-32) compared to temperate forests (Hale, 1966; Fjellberg, 1976; Petersen, 1982; Uvarov \& Byzova, 1995). Thus, we may generalize that small-scale microclimatic gradients in karst landforms, characterized by distinct soil microclimatic and vegetation conditions, are analogous to the latitudinal patterns of biomes from deciduous forests to tundra.

\section{Exceptional diversity of Collembola in a unique karst landform}

The collapse doline of the Silická ladnica Ice Cave is a unique phenomenon with a strongly inverted microclimate gradient within a small area, leading 
to distinct Collembola communities (considerable species turnover along the gradient) and considerably high alpha diversity. The local biodiversity of natural karst landforms in the landscape have been greatly overlooked. Several studies pointed out that diverse geomorphology determines the richness of the plant and animal communities. This is especially true for a karst landscape evolved on limestone bedrock that is characterized by diverse environmental conditions with apparent microclimatic gradients in dolines, ravines, sinkholes and deep valleys (gorges) that may be considered as natural "habitat islands", the key habitats for wider spectrum of endemic species and relicts (e.g., Ložek, 1972; Breg, 2007; Raschmanová et al., 2008; Cernatič-Gregorič \& Zega, 2010; Villisics et al., 2011; Bátori et al., 2014; Su et al., 2017). Our study documented that the small area of the collapse doline of the Silická ladnica supports exceptional diversity of soil Collembola. Only half of the total number of species was recorded during the first year 2005 (Raschmanová et al., 2015). Observations longer than one-year and effective and non-destructive soil sampling designs may reveal the real biodiversity of these unique karst landforms. Soil sampling over three years resulted in a very high species richness, i.e., 129 species altogether, including six species new for science and two first records for Slovakia. This number was close to the estimated species richness (143 species), showing that we recorded $91 \%$ of estimated species richness during the study. The Central European mountains harbor a unique and major component of biological diversity in the temperate zone (Köck et al., 2014; Mráz \& Ronikier, 2016). For instance, Stach (1959) recorded 134 species in the High Tatra Mountains in Poland, Nosek (1969) 211 species in the Low Tatra Mountains in Slovakia, Čuchta \& Shrubovych (2015) 209 species in the Bohemian Forest in the Czech Republic, Smolis \& Skarzynski (2003) 118 species in the Beskid Niski Mts in Poland, and Weiner (1981) 191 species in the Pieniny Mts in Poland. However, an appropriate comparison of Collembola species numbers between the different studies is difficult due to the non-uniform sampling schemes (number and size of soil samples, size of the study area and length of the sampling period). Finally, our results suggest that karst surface landforms harbour considerable alpha diversity that may reach over 100 Collembola species. Despite the high biodiversity documented for heterogenous karst habitats, its substantial part may be still underestimated due to the cryptic diversity that has been revealed in some Collembola genera (e.g., Porco et al., 2012; Zhang et al., 2014; Katz et al., 2015). It was found that cryptic diversity is underestimated in terms of global species richness (Cicconardi et al., 2013) and rarely included in conservation programs (Scriven et al., 2015), although cryptic species may be seriously threatened in temperature gradients of karst landforms (Raschmanová et al., 2017). Based on this study and the previous studies conducted in the Slovak Karst, which covers 362 km² (Kováč et al., 1997; Kováč, 1999; Kováč et al., 2005; Raschmanová et al., 2008; 2015;
2017), this karst region comprises $\sim 257$ collembolan species occupying various soil habitats.

\section{Importance of the microclimatic gradient in preserving cold-adapted/psychrophilic species in karst landforms}

In Central Europe cold-adapted species often have disjunctive distributions at high altitude habitats in mountains, but also at low altitudes, where their isolated populations are restricted to specific habitats, such as cold scree slopes (Ružička, 2011) and the bottoms of dolines, deep ravines and sinkholes in karst areas with a prominent inversion of microclimate (Raschmanová et al., 2008; Vilisics et al., 2011). Montane species and species with a boreo-montane disjunction range shared $16 \%$ of total richness. The numbers of cold-adapted species increased at sites from the doline bottom to the plateau edge (except two upper sites), whereas their mean abundances showed an opposite trend. Psychrophilic species may be considered as rare at lower altitudes, where they have fragmented distribution ranges and usually also low abundances (e.g., Gaston, 1997). These species are particularly vulnerable to habitat changes and disturbances resulting in the decline of their distribution range and population size (Fattorini et al., 2013). Three psychrophilic species were abundant at cold sites, namely C. sigillata, P. armata and the cryptic species Folsomia sp., being known to prefer soils that tend to be moist and cold (Zettel \& Zettel, 1994; Pomorski, 1998; Raschmanová et al., 2017). C. sigillata and Folsomia sp. were abundant at the bottom of the doline in spring, when the soil there is usually frozen and covered by snow. Superodontella tyverica was recorded exclusively at an extremely cold site near the floor ice, in primary soil on stony debris with mosses and liverworts. It was previously known only from forest soils of mountain and subalpine ecosystems in Ukraine (Kaprus, 2009), and this is the first record of this species in Slovakia. On the other hand, some montane species, such as Sminthurinus bimaculatus and two species with boreo-montane distribution, namely Micranurida granulata and Lepidocyrtus szeptickyi, were recorded exclusively at warm sites; however, the latter two species in very low abundance.

\section{Endemic and relict species at sites in the collapse doline}

Endemic species are considered to be the most valuable and vulnerable components of soil biota and have the highest conservation value (e.g., Deharveng et al., 2000; Nitzu et al., 2018). Carpathian and Western Carpathian endemics shared $8 \%$ of overall richness. Two endemics, Endonura dudichi and Pumilinura loksai, were distributed in the middle and upper zone of the gradient slope in relation to their known association with thermophilous forest soils (e.g., Raschmanová et al., 2008; Smolis, 2008). Climate relict populations of various terrestrial taxa were more widely distributed in the temperate zone in the past, when climatic conditions were more conducive to a greater range (Culver \& Pipan, 2009; Habel, 2010; 
Hampe \& Jump, 2011). Typical subterranean species, referred to as climate relicts, occupied cold sites at the bottom of the doline, namely Megalothorax carpaticus and Pygmarrhopalites aggtelekiensis, which are Western Carpathian endemics. M. carpaticus (a facultative cave species) is a eutroglophilous species known from various caves of alpine karst or cold caves situated at lower elevations, including cave entrances (Kováč et al., 2016). Based on the wide distribution in both karst and pseudokarst caves of the Carpathian Mts. and the slightly developed troglomorphic characters (morphological adaptations to subterranean environment), $M$. carpaticus may be considered as younger, glacial relict. The species was also recorded in the Gombasecká Cave, which belongs to the same cave system with the Silická ladnica Ice Cave. In contrast, the troglobiont $P$. aggtelekiensis (an obligate cave species) shows very well developed troglomorphic traits and a distribution limited to caves in a few central and southern karst regions of the Western Carpathians; thus, it is presumably a descendant of the older lineage with Tertiary origin, considered to be a climate and phyletic relict (Kováč et al., 2016).

It is important to note that soil habitats (aphotic environment close to the surface) themselves are the kind of the shallow subterranean habitats which are inhabited with characteristic subterranean fauna, including both generalists and troglobionts (e.g., Pipan et al., 2011; Culver \& Pipan, 2014; Rendoš et al., 2016; etc.). Generally, subterranean fauna is adapted to the stable microclimatic conditions of the subterranean environment (e.g., Culver \& Pipan, 2009). In fact, the sites at the bottom of the collapse doline represent a transition habitat (ecotone in the sense of Prous et al., 2015) between the surface and subterranean environments and is characterized by relatively high soil moisture and stable cold soil temperature throughout the year, documented by low differences between soil temperature maxima and minima. $P$. aggtelekiensis as an obligate cave species is probably able to migrate between deep scree layers at the bottom of doline and the cave, where it has been found in greater numbers (Kováč \& Papáč, unpublish.). The occurrence of $P$. aggtelekiensis in the soil at a cold site in October 2007 was probably linked with the exceptionally wet climate in this season, with extreme monthly precipitation. The external climatic conditions in this part of year $\left(8^{\circ} \mathrm{C}\right)$ were thus similar to the internal climate of this cave, where unglaciated spaces have an annual air temperature of $6.8^{\circ} \mathrm{C}$ (Roda et al., 1974). Furthermore, these climate conditions $\left(6.8-8^{\circ} \mathrm{C}\right)$ are analogous to the internal climate of most local caves (e.g., Kováč et al., 2016). This is the first occurrence of this troglobiont species outside of caves. Cold and wet scree sites at the karst doline bottom have favourable conditions that may constitute a borderline habitat for obligate subterranean species. Generally, bare and forested scree habitats represent a unique habitat with their own fauna, but they also play the role of an ecotone, in which both epigean and obligate subterranean forms thrive (e.g., Ortuño et al., 2013; Rendoš et al., 2016; Mammola et al., 2017).

\section{Anthropogenic and environmental biodiversity threats}

The negative effect of anthropogenic activities and climatic change on soil biodiversity has become a major topic in conservation biology (Harte et al., 1995; Rusek, 1996; Addo-Bediako, 2000; Habel et al., 2010; Alatalo et al., 2015). For instance, deforestation of the karst landscape may profoundly affect climatic gradient environments by the temperature increase and decrease of soil moisture content. Many experimental field studies in polar and tundra habitats have shown that simulated temperature increase, or periods of drought, resulted in lower abundances and/or richness of Collembola (Tsiafouli et al., 2005; Briones et al., 2009; Petersen, 2011; Alatalo et al., 2015). The effect of climate change on soil organisms may be different at the population and community levels (e.g., Convey et al., 2002; Convey \& Wynn-Williams, 2002; Daly et al., 2010; Alatalo et al., 2017). Hågvar \& Klanderud (2009) concluded that collembolan species with a life cycle longer than one year were rather resistant to climate change during long-term warming experiment in subarctic habitats. The same climatic change may have a different effect on soil fauna in habitats of different climatic zones, biomes and ecosystems (Rusek, 1996; Hodkinson et al., 1998; Sjursen et al., 2005). Růžička et al. (2015) concluded that the microclimate of some low-altitude cold talus ecosystems in the temperate zone may be sufficiently resistant to an increase of mean annual atmospheric temperature from global warming by $3^{\circ} \mathrm{C}$. Thus, scree deposits on mountains slopes function as climatic microrefugia for cold-adapted species.

Finally, there is the reasonable threat to the floor ice at the cave entrance of Silická ladnica Ice Cave. This is documented by an increasing trend in the annual air temperature means observed by the local meteorological station in the period 2010-2016 (between 7.7 and $10.1^{\circ} \mathrm{C}$ ). In addition, Fendeková et al. (2018) reported marked temperature increases (warming) in the whole territory of Slovakia in 2011-2015 based on long-term climate observations carried out from 1981. The Silická ladnica Ice Cave is indeed a unique natural phenomenon in a temperate zone with perennial ice accumulations at the cave entrance and a profound climatic gradient along the slope from the bottom of the collapse doline to the edge of the karst plateau. Long-term observations are needed in order to better understand what the response of the local soil fauna communities will be to climatic changes. It is at least necessary to maintain primeval forests in the surrounding karst landscape to moderate the potential impacts of climate change on the microclimatic gradients in landforms and their associated biota (Bátori et al., 2014).

\section{CONCLUSIONS}

First, our study documented that the local (alpha) diversity of soil Collembola in a karst landform with a pronounced climatic gradient may be very high in the temperate zone, thus serving as a reservoir of exceptional soil fauna diversity. Small-scale 
microclimatic gradients within the diverse karst relief are reflected by the presence of endemic species and psychrophilic forms, some of them considered to be relicts surviving in isolation in the same area from colder periods. Such conditions lead to local species differentiation and evolution of cryptic diversity that highlights the biological value of natural temperature gradients in karst landforms and the importance of their conservation. Second, the cold and wet part of the scree slope in a collapse doline serves as an ecotone between subterranean (cave) habitats and the surface environment that is supported by the occurrence of troglobiotic species. Third, cold microhabitats at the doline bottom will be under threat of global climate warming; therefore, these habitats should be central in conservation priorities and management of natural habitats. Finally, karst landforms with distinctly inverted climatic gradients are excellent areas for long-term monitoring of climate change and its effect on the alpha diversity of biota.

\section{ACKNOWLEDGEMENTS}

The study was supported by Slovak Scientific Grant Agency project no. 1/0199/14 and 1/0346/18, and project Centre of Excellence for Parasitology (code ITMS: 26220120022). Dr. P. Luptáčik (P.J. Šafarik University, Košice, Slovakia) is acknowledged for assistance during the field work. We are grateful to D.L. McLean for linguistic correction of the manuscript and two anonymous reviewers for their constructive comments.

\section{REFERENCES}

Addo-Bediako A., Chown S.L. \& Gaston K.J., 2000 Thermal tolerance, climatic variability and latitude. Proceedings of the Royal Society of London Series B: Biological Sciences, 267: 739-745.

https://doi.org/10.1098/rspb.2000.1065

Alatalo J.M., Jägerbrand A.K. \& Čuchta P., 2015 Collembola at three alpine subarctic sites resistant to twenty years of experimental warming. Scientific Reports, 5: 18161. https://doi.org/10.1038/srep18161

Alatalo J.M., Jägerbrand A.K., Juhanson J., Michelsen A. \& L'uptáčik P., 2017 - Impacts of twenty years of experimental warming on soil carbon, nitrogen, moisture and soil mites across alpine/subarctic tundra communities. Scientific Reports, 7: 44489.

https://doi.org/10.1038/srep44489

Bardgett R.D., Bowman W.D., Kaufmann R. \& Schmidt S.K., 2005 - A temporal approach to linking aboveground and belowground ecology. Trends in Ecology and Evolution, 20: 634-641. https://doi.org/10.1016/j.tree.2005.08.005

Bátori Z., Gallé R., Erdős L. \& Körmöczi L., 2011 Ecological conditions, flora and vegetation of a large doline in the Mecsek Mountains (South Hungary). Acta Botanica Croatica, 70: 147-155.

https://doi.org/10.2478/v10184-010-0018-1

Bátori Z., Körmöczi L., Erdős L., Zalatnai M. \& Csiky J., 2012 - Importance of karst sinkholes in preserving relict, mountain, and wetwoodland plant species under sub-Mediterranean climate: A case study from southern Hungary. Journal of Cave and Karst Studies, 74: 127-134. https://doi.org/10.4311/2011LSC0216
Bátori Z., Csiky J., Farkas T., Vojtko A.E., Erdős L., Kovács D., Wirth T., Körmöczi L. \& Vojtkó A., 2014 - The conservation value of karst dolines for vascular plants in woodland habitats of Hungary: refugia and climate change. International Journal of Speleology, 43 (1): 15-26.

https://doi.org/10.5038/1827-806X.43.1.2

Bátori Z., Vojtkó A., Farkas T., Szabó A., Havadtöi K., Vojtkó A.E., Tölgyesi C., Cseh V., Erdős L., Maák I.E. \& Keppel G., 2017 - Large- and small-scale environmental factors drive distributions of cool-adapted plants in karstic microrefugia. Annals of Botany, 119: 301-309. https://doi.org/10.1093/aob/mcw233

Bella P. \& Zelinka J., 2018 - Ice caves in Slovakia. In: Perşoiu A. \& Lauritzen S.E. (Eds.), Ice caves. Elsevier, Amsterdam, p. 657-689.

https://doi.org/10.1016/B978-0-12-811739-2.00029-2

Breg M., 2007 - Degradation of dolines on Logaško Polje (Slovenia). Acta Carsologica, 36 (2): 223-231.

https://doi.org/10.3986/ac.v36i2.191

Bretfeld G., 1999 - Symphypleona. In: Dunger W. (Ed.), Synopses on Palaearctic Collembola, Volume 2. Abhandlungen und Berichte des Naturkundemuseum Gőrlitz, 318 p.

Briones M.J., Ostle J.J., McNamara N.P. \& Poskitt J., 2009 - Functional shifts of grassland soil communities in response to soil warming. Soil Biology and Biochemistry, 41 (2): 315-322.

https://doi.org/10.1016/j.soilbio.2008.11.003

Brose U., Martinez N.D. \& Williams R.J., 2003 Estimating species richness: sensitivity to sample coverage and insensitivity to spatial patterns. Ecology, 84: 2364-2377.

https://doi.org/10.1890/02-0558

Buddle C.M., Beguin J., Bolduc E., Mercado A., Sackett T.E., Selby R.D., Varady-Szabo H. \& Zeran R.M., 2005 - The importance and use of taxon sampling curves for comparative biodiversity research with forest arthropod assemblages. The Canadian Entomologist, 137: 120-127. https://doi.org/10.4039/n04-040

Cernatič-Gregorič A. \& Zega M., 2010 - The impact of human activities on dolines (sinkholes) - typical geomorphologic features on karst (Slovenia) and possibilities of their preservation. Geographica Pannonica, 14 (4): 109-117. https://doi.org/10.5937/GeoPan1004109C

Chao A., 1987 - Estimating the population size for capturerecapture data with unequal catchability. Biometrics, 43: 783-791. https://doi.org/10.2307/2531532

Chao A., Chazdon R.L., Colwell R.K. \& Shen T.J., 2005 A new statistical approach for assessing compositional similarity based on incidence and abundance data. Ecology Letters, 8: 148-159. https://doi.org/10.1111/j.1461-0248.2004.00707.x

Cicconardi F., Fanciulli P.P. \& Emerson B.C., 2013 Collembola, the biological species concept, and the underestimation of global species richness. Molecular Ecology, 22: 5382-5396.

https://doi.org/10.1111/mec. 12472

Colwell R.K., 2013 - Estimates: Statistical estimation of species richness and shared species from samples. Version 9. User's Guide and application. http://purl.oclc.org/estimates

Colwell R.K., Chao A., Gotelli N.J., Lin Shang-Yi., Xuan Mao Ch., Chazdon R.L. \& Longino J.T., 2012 - Models and estimators linking individual-based and samplebased rarefaction, extrapolation, and comparison of assemblages. Journal of Plant Ecology, 5: 3-21. https://doi.org/10.1093/jpe/rtr044 
Convey P., Pugh P.J.A., Jackson C., Murray A.W., Ruhland C.T., Xion F.S. \& Day A., 2002 - Response of antarctic terrestrial microarthropods to long-term climate manipulations. Ecology, 83: 3130-3140.

https://doi.org/10.1890/0012-9658(2002)083 [3130:ROATMT]2.0.CO;2

Convey P. \& Wynn-Williams D.D., 2002 - Antarctic soil nematode response to artificial climate amelioration. European Journal of Soil Biology, 38 (3-4): 255-259. https://doi.org/10.1016/S1164-5563(02)01155-X

Crossley D.A. \& Blair J.M., 1991 - A high efficiency, "lowtechnology" Tullgren-type extractor for soil microarthropods. Agriculture, Ecosystems and Environment, 34 (1-4): 187-192.

https://doi.org/10.1016/0167-8809(91)90104-6

Culver D.C. \& Pipan T., 2009 - The Biology of Caves and Other Subterranean Habitats. Oxford University Press, New York, 254 p.

Culver D.C. \& Pipan T., 2014 - Shallow subterranean habitats. Ecology, evolution and conservation. Oxford University Press, Oxford, 258 p. https://doi.org/10.1093/acprof:oso/9780199646173. $\underline{001.0001}$

Čuchta P. \& Shrubovych J., 2015 - Soil Collembola communities in montane coniferous forests of the Bohemian Forest. Silva Gabreta, 21 (2): 149-156.

Daly C., Conklin D.R. \& Unsworth M.H., 2010 - Local atmospheric decoupling in complex topography alters climate change impacts. International Journal of Climatology, 30: 1857-1864. https://doi.org/10.1002/joc.2007

Deharveng L., Dalens H., Drugmand D., Simon-Benito J.C., Da Gama M.M., Sousa P., Gers C. \& Bedos A., 2000 - Endemism mapping and biodiversity conservation in western Europe: an Arthropod perspective. Belgian Journal of Entomology, 2: 59-75.

Dobrowski S.Z., 2010 - A climatic basis for microrefugia: the influence of terrain on climate. Global Change Biology, 17: 1022-1035.

https://doi.org/10.1111/j.1365-2486.2010.02263.x

Dunger W. \& Schlitt B., 2011 - Onychiuroidea: Tullbergiidae. Synopses on Palaearctic Collembola, Volume 6, Part 1. Senckenberg Museum of Natural History Gőrlitz, 168 p.

Fattorini S., Di Giulio A. \& Dapporto L., 2013 - Measuring insect rarity: practical issues, pragmatic approaches. Journal of Insect Biodiversity, 1 (10): 1-21. https://doi.org/10.12976/jib/2013.1.10

Fendeková M., Poórová J. \& Slivová V., 2018 Hydrologické sucho na Slovensku a prognóza jeho vývoja. Bratislava: Comenius University, 300 p.

Fjellberg A., 1976 - Collembola from Mountains of South Norway. Norwegian Journal of Entomology, 23: 127-137.

Fjellberg A., 1998 - The Collembola of Fennoscandia and Denmark. Part I: Poduromorpha. Fauna Entomologica Scandinavica, vol. 35. Brill, Leiden-Boston-Kőln, 184 p.

Fjellberg A., 2007 - The Collembola of Fennoscandia and Denmark, Part II: Entomobryomorpha and Symphypleona. Fauna Entomologica Scandinavica, 42: $1-264$.

https://doi.org/10.1163/ej.9789004157705.i-265

Fleishman E., Noss R.F. \& Noon B.R., 2006 - Utility and limitations of species richness metrics for conservation planning. Ecological Indicators, 6: 543-553.

https://doi.org/10.1016/j.ecolind.2005.07.005

Gaston K.J., 1997 - What is rarity? In: Kunin W.E. \& Gaston K.J. (Eds.), The biology of rarity. Chapman \& Hall, London, p. 30-47.

https://doi.org/10.1007/978-94-011-5874-9_3
Gaston K.J., 2000 - Global patterns in biodiversity. Nature, 405: 220-227.

https://doi.org/10.1038/35012228

Giller P.S., 1996 - The diversity of soil communities, "the poor man's tropical rainforest". Biodiversity and Conservation, 5: 135-168.

https://doi.org/10.1007/BF00055827

Habel J.C. \& Assmann T., 2010: - Relict species: Phylogeography and conservation biology. Springer, Berlin, 449 p.

https://doi.org/10.1007/978-3-540-92160-8

Hale W.G., 1966 - A population study of moorland Collembola. Pedobiologia, 6: 65-99.

Hampe A. \& Jump A.S., 2011- Climate Relicts: Past, Present, Future. Annual Review of Ecology, Evolution and Systematics, 42: 313-333.

https://doi.org/10.1146/annurev-ecolsys-102710$\underline{145015}$

Harte J., Torn M.S., Chang F.R., Feifarek B., Kinzig A.P., Shaw R. \& Shen K., 1995 - Global warming and soil microclimate: results from a meadow-waming. Ecological Aplications, 5 (1): 132-150.

https://doi.org/10.2307/1942058

Hågvar S. \& Klanderud K., 2009 - Effect of simulated environmental change on alpine soil arthropods. Global Change Biology, 15 (12): 2972-2980.

https://doi.org/10.1111/j.1365-2486.2009.01926.x

Hodkinson I.D., Webb N.R., Bale J.S., Block W., Coulson S.J. \& Strathdee A.T., 1998 - Global change and arctic ecosystems: conclusions and predictions from experiments with terrestrial invertebrates on Spitsbergen. Arctic and Alpine Research, 30: 306-331. https://doi.org/10.2307/1551978

Hofierka J., Gallay M., Bandura P. \& Šašak J., 2018 - Identification of karst sinkholes in a forested karst landscape using airborne lasser scanning data and water flow analysis. Geomorphology, 308: 265-277. https://doi.org/10.1016/j.geomorph.2018.02.004

Kaprus I.J., 2009 - Superodontella STACH,, 1949 (Collembola, Odontellidae) of Ukraine: new species, comparative morphological analysis and distribution. Acta Zoologica Cracoviensia, 52B (1-2): 21-34. https://doi.org/10.3409/azc.52b_1-2.21-34

Katz A.D., Giordanoo R. \& Soto-Adames F.N., 2015 Operational criteria for cryptic species delimitation when evidence is limited, as exemplified by North American Entomobrya (Collembola: Entomobryidae). Zoological Journal of the Linnean Society, 173: 818-840. https://doi.org/10.1111/zoj.12220

Kováč L., 1999 - Stachorutes ruseki sp. n. (Collembola, Neanuridae) from Slovakia. Biologia, 54: 135-138.

Kováč L'., Kostúrová N. \& Miklisová D., 2005 - Comparison of collembolan assemblages (Hexapoda, Collembola) of thermophilous oak woods and Pinus nigra plantations in the Slovak Karst (Slovakia). Pedobiologia, 49 (1): 2940. https://doi.org/10.1016/j.pedobi.2004.07.009

Kováč L., Parimuchová A. \& Miklisová D., 2016 Distributional patterns of cave Collembola (Hexapoda) in association with habitat conditions, geography and subterranean refugia in the Western Carpathians. Biological Journal of the Linnean Society, 119: 571592. https://doi.org/10.1111/bij. 12555

Kováč L., Takáčová M. \& Rozložník M., 1997 - Soil arthropod communities of the Slovak Karst Biosphere Reserve with special reference to Collembola (Hexapoda). Proc. Conference Research, Conservation, Management Aggtelek, 1: 427-436.

Köck M., Tudor P., Verghelet M., Hoffmann Ch., Favilli F., Elmi M., Alberton M., Meyer H., Kadlečik J. \& Sipos K., 2014 - BioREGIO Carpathians. Integrated management 
of biological and landscape diversity for sustainable regional development and ecological connectivity in the Carpathians. UNEP Vienna, 76 p.

Králová M., Dražd’ák K., Pospíšil F., Hadáčová V., Klozová E., Luštinec J., Kutáček M. \& Dahulka J., 1991 Vybrané metódy chemickej analýzy pưd a rostlin. Academia, Praha, 152 p.

Ložek V., 1972 - The Karst and the Mollusca. Československý kras, 21: 7-22.

Mammola S., Piano E., Giachino P.M. \& Isaia M., 2017 - An ecological survey of the invertebrate community at the epigean/hypogean interface. Subterranean Biology, 24: 27-52.

https://doi.org/10.3897/subtbiol.24.21585

Mráz P. \& Ronikier M., 2016 - Biogeography of the Carpathians: evolutionary and spatial facets of biodiversity. Biological Journal of the Linnean Society, 119: 528-559.

https://doi.org/10.1111/bij.12918

Nitzu E., Vlaicu M., Giurginca A., Meleg I.N., Popa I., Nae A. \& Baba S., 2018 - Assessing preservation priorities of caves and karst areas using the frequency of endemic cave-dwelling species. International Journal of Speleology, 47 (1): 43-52. https://doi.org/10.5038/1827-806X.47.1.2147

Nosek J., 1969 - The investigation on the Apterygotan fauna of the Low Tatras. Acta Universitatis CarolinaeBiologica, 1967: 349-528.

Ortuño V.M., Gilgado J.D., Jiménez-Valverde A., Sendra A., Pérez-Suárez G. \& Herrero-Borgoñón J.J., 2013 - The "alluvial mesovoid shallow substratum", a new subterranean habitat. PLoS ONE, 8 (10): e76311. https://doi.org/10.1371/journal.pone.0076311

Petersen H., 1982 - Structure and size of soil animal populations. Oikos, 39: 306-329. https://doi.org/10.2307/3544689

Petersen H., 2011 - Collembolan communities in shrublands along climatic gradients in Europe and the effect of experimental warming and drought on population density, biomass and diversity. Soil Organisms, 83 (3): 463-488.

Petersen H. \& Luxton M., 1982 - A comparative analysis of soil fauna populations and their role in decomposition processes. Oikos, 39 (3): 288-388. https://doi.org/10.2307/3544689

Petrášová A. \& Šuvada R., 2008 - Bryofloristicko-ekologická štúdia Národného parku Slovenský kras. Bulletin Slovenskej Botanickej Spoločnosti, 30 (2): 169-177.

Pipan T., López H., Oromí P., Polak S. \& Culver D.C., 2011 - Temperature variation and the presence of troglobionts in terrestrial shallow subterranean habitats. Journal of Natural History, 45 (3-4): 253-273.

https://doi.org/10.1080/00222933.2010.523797

Pomorski R.J., 1998 - Onychiurinae of Poland (Collembola, Onychiurinae). Biologica Silensiae Turzanski, Wroclaw, 201 p.

Porco D., Potapov M., Bedos A., Busmachiu G., Weiner W.M., Hamra- Kroua S. \& Deharveng L., 2012 - Cryptic diversity in the Ubiquist species Parisotoma notabilis (Collembola, Isotomidae): a long-used chimeric species? PLoS ONE, 7 (9): e46056.

https://doi.org/10.1371/journal.pone.0046056

Potapov M., 2001 - Isotomidae. In: Dunger W. (Ed.), Synopses on Palearctic Collembola (Vol. 3). State Museum of the Natural History Museum of Görlitz, 603 p.

Prous X., Ferreira R.L. \& Jacobi C.M., 2015 - The entrance as a complex ecotone in a Neotropical cave. International Journal of Speleology, 44 (2): 177-189. https://doi.org/10.5038/1827-806X.44.2.7
Raschmanová N., Kováč L. \& Miklisová D., 2008 - The effect of mesoclimate on Collembola diversity in the Zádiel Valley, Slovak Karst (Slovakia). European Journal of Soil Biology, 44: 463-472.

https://doi.org/10.1016/j.ejsobi.2008.07.005

Raschmanová N., Miklisová D. \& Kováč L., 2013 - Soil Collembola communities along a steep microclimatic gradient in the collapse doline of the Silická ladnica Cave, Slovak Karst (Slovakia). Biologia, 68 (3): 470-478. https://doi.org/10.2478/s11756-013-0172-8

Raschmanová N., Miklisová D., Kováč L. \& Šustr V., 2015 - Community composition and cold tolerance of soil Collembola in a collapse karst doline with strong microclimate inversion. Biologia, 70 (6): 802-811. https://doi.org/10.1515/biolog-2015-0095

Raschmanová N., Miklisová D. \& Kováč L., 2016 Dynamics of soil Collembola communities (Hexapoda: Collembola) along the mesoclimatic gradient in a deep karst valley. Biologia, 71 (2): 184-193.

https://doi.org/10.1515/biolog-2016-0019

Raschmanová N., Žurovcová M., Kováč L., Paučulová L., Šustr V., Jarošová A. \& Chundelová D., 2017 The cold-adapted population of Folsomia manolachei (Hexapoda, Collembola) from a glaciated karst doline of Central Europe: evidence for a cryptic species? Journal of Zoological Systematics and Evolutionary Research, 55 (1): 19-28. https://doi.org/10.1111/jzs.12150

Rendoš M., Raschmanová N., Kováč L., Miklisová D., Mock A. \& L'uptáčik P., 2016 - Organic carbon content and temperature as substantial factors affecting diversity and vertical distribution of Collembola on forested scree slopes. European Journal of Soil Biology, 75: 180-187. https://doi.org/10.1016/j.ejsobi.2016.06.001

Roda Š., Rajman L. \& Erdös M., 1974 - Výskum mikroklimy a dynamiky zal'adnenia $v$ Silickej ladnici. Slovenský kras, 12: 157-174.

Rozložník M., Szöllös F., Uhrin M. \& Karasová E., 1994 - Slovenský kras - Slovak Karst Biosphere Reserve. In: Jeník J. \& Price F. (Eds.), Biosphere Reserves on the Crossroads of Central Europe, Czech Republic - Slovak Republic. Czech National Committee for UNESCO's MaB programme, Empora, Prague, p. 113-128.

Rull V., 2009 - Microrefugia. Journal of Biogeography, 36: 481-484.

https://doi.org/10.1111/j.1365-2699.2008.02023.x

Rusek J., 1996 - Global change impact on soil fauna and ecosystems. In: Nemešová I. (Ed.), Climate variability and climate change vulnerability and adaptations. Prague: Inst. Atmosph. Physics, Acad. Sci CR, p. 163-170.

Růžička V., 2011 - Central European habitats inhabited by spiders with disjunctive distributions. Polish Journal of Ecology, 59: 367-380.

Růžička V., Zacharda M., Šmilauer P. \& Kučera T., 2015 Can paleorefugia of cold-adapted species in talus slopes resist global warming? Boreal Environment Research, 20: 403-412.

Schneider K. \& Culver D.C., 2004 - Estimating subterranean species richness using intensive sampling and rarefaction curves in a high density cave region in West Virginia. Journal of Cave and Karst Studies, 66 (2): 39-45.

http://ww.caves.org/pub/journal/PDF/V66/v66n2Schneider.pdf

Scriven J.J., Woodall L.C., Tinsley M.C., Knight M.E., Williams P.H., Carolan J.C., Brown M.J.F. \& Goulson D., 2015 - Revealing the hidden niches of cryptic bumblebees in Great Britain: Implications for conservation. Biological Conservation, 182: 126-133. https://doi.org/10.1016/j.biocon.2014.11.027 
Sjursen H., Michelsen A. \& Holmstrup M., 2005 - Effects of freeze-thaw cycles on microarthropods and nutrient availability in a sub-Arctic soil. Applied Soil Ecology, 28 (1): 79-93.

https://doi.org/10.1016/j.apsoil.2004.06.003

Smolis A., 2008 - Redescription of four Polish Endonura Cassagnau, 1979 (Collembola, Neanuridae, Neanurinae), with a nomenclature of the ventral chaetae of antennae. Zootaxa, 1858: 9-36.

Smolis A. \& Skarzyński D., 2003 - Springtails (Collembola) of the "Przelom Jasiolki" reserve in the Beskid Niski Mountains (Polish Carpathians). Fragmenta Faunistica, 46: 121-129.

https://doi.org/10.3161/00159301FF2003.46.2.121

Stach J., 1959 - The Apterygotan fauna of the Polish Tatra National Park. Acta Zoologica Cracoviensia, 4 (1): 1-102.

Su Y., Tang O., Mo F. \& Xue Y., 2017 - Karst tiankengs as refugia for indigenous tree flora amidst a degraded landscape in southwestern China. Scientific Reports, 7: 4249. https://doi.org/10.1038/s41598-017-04592-x

Tews J., Brose U., Grimm V., Tielbörger K., Wichmann M.C., Schwager M. \& Jeltsch F., 2004 - Animal species diversity driven by habitat heterogeneity/diversity: the importance of keystone structures. Journal of Biogeography, 31: 79-92.

https://doi.org/10.1046/j.0305-0270.2003.00994.x

TIBCO Software Inc., 2013 - STATISTICA (data analysis software system), version 12. https://www.tibco.com/ products/tibco-statistica

Thibaud J.M., Schulz H.J. \& da Gama Assalino M.M., 2004 - Hypogastruridae, In: Dunger W. (Ed.), Synopses on Palearctic Collembola, Volume 4. State Museum of the Natural History Museum of Görlitz, 287 p.
Tsiafouli M.A., Kallimanis A.S., Katana E., Stamou G.P. \& Sgardelis S.P., 2005 - Responses of soil microarthropods to experimental short-term manipulations of soil moisture. Applied Soil Ecology, 29: 17-26.

https://doi.org/10.1016/j.apsoil.2004.10.002

Uvarov A.V. \& Byzova J.B., 1995 - Species diversity and distribution of Collembola in the vicinity of Polish Polar Station, Hornsund area, Spitsbergen. Polish Polar Research, 16 (3-4): 233-243.

Vilisics F., Solymos P., Nagy A., Farkas R., Kemencei Z. \& Hornung E., 2011 - Small scale gradient effects on isopods (Crustacea: Oniscidea) in karstic sinkholes. Biologia, 66 (3): 499-505. https://doi.org/10.2478/s11756-011-0042-1

Weiner W.M., 1981 - Collembola of the Pieniny National Park in Poland. Acta Zoologica Cracoviensia, 25 (18): 417-500.

Wynne J.J., Bernard E.C., Howarth F.G., Sommer S., Soto-Adames F.N., Taiti S., Mockford E.L., Horrocks M., Pakarati L. \& Pakarati-Hotus V., 2014 - Disturbance relicts in a rapidly changing world: the Rapa Nui (Easter Island) factor. BioScience, 64 (8): 711-718. https://doi.org/10.1093/biosci/biu090

Yao Z., Dong T., Zheng G., Fu J. \& Li S., 2016 - High endemism at cave entrances: a case study of spiders of the genus Uthina. Scientific Reports, 6: 35757.

Zettel J. \& Zettel U., 1994 - Development, phenology and surface activity of Ceratophysella sigillata (Uzel) (Collembola, Hypogastruridae). Acta Zoologica Fennica, 195: 150-153.

Zhang F., Yu D.Y., Luo Y.Z., Ho S.Y.W., Wang B.X. \& Zhu C.D., 2014 - Cryptic diversity, diversification and vicariance in two species complexes of Tomocerus (Collembola, Tomoceridae) from China. Zoologica Scripta, 43: 393- 404. https://doi.org/10.1111/zsc.12056 
Appendix. List of soil Collembola at sites in the collapse doline, their mean abundance (ind. $\mathrm{m}^{-2}$ ) during 2005-2007 and their ecological and geographical characteristics.

\begin{tabular}{|c|c|c|c|c|c|c|c|c|c|}
\hline Abbrev. & Group & Species & 1 & 2 & 3 & 4 & 5 & 6 & 7 \\
\hline \multirow[t]{2}{*}{$\mathrm{H}$} & $\mathrm{e}$ & Allacma fusca (L., 1758) & 8 & - & - & - & 8 & 47 & 47 \\
\hline & $\mathrm{e}$ & Bourletiella sp. juv. & - & - & - & - & - & 8 & - \\
\hline $\mathrm{E}$ & $\mathrm{e}$ & Caprainea marginata (Schött, 1893) & - & - & - & - & 55 & 85 & - \\
\hline $\mathrm{H}$ & $\mathrm{G}$ & Ceratophysella armata (Nicolet, 1841) & - & - & - & - & 4 & - & 17 \\
\hline $\mathrm{C}$ & $\mathrm{G}$ & Ceratophysella denticulata (Bagnall, 1941) & - & 13 & - & 34 & 25 & - & 4 \\
\hline $\mathrm{E}$ & $\mathrm{G}$ & Ceratophysella engadinensis (Gisin, 1949) & 13 & - & - & - & 34 & - & 25 \\
\hline $\mathrm{M}$ & $\mathrm{G}$ & Ceratophysella granulata Stach, 1949 * & - & - & 8 & - & - & - & - \\
\hline $\mathrm{M}$ & $\mathrm{e}$ & Ceratophysella sigillata (Uzel, 1891) * & 28990 & 4522 & 2289 & 3316 & 327 & 64 & 89 \\
\hline $\mathrm{M}$ & $\mathrm{e}$ & Ceratophysella silvatica (Rusek, 1964)* & - & - & - & - & - & 13 & 21 \\
\hline $\mathrm{M}$ & $\mathrm{e}$ & Desoria propinqua (Axelson, 1902) * & 64 & 217 & - & - & - & - & - \\
\hline $\mathrm{C}$ & $\mathrm{e}$ & Desoria tigrina Nicolet, 1842 & 17 & 1775 & 425 & 2161 & 13 & 4 & 17 \\
\hline \multirow[t]{2}{*}{$\mathrm{U}$} & $\mathrm{e}$ & Deuteraphorura cebennaria (Gisin, 1956) & - & 38 & - & - & - & - & - \\
\hline & $\mathrm{e}$ & Deuterosminthurus sp. juv. & - & - & - & - & - & 4 & - \\
\hline $\mathrm{M}$ & $\mathrm{e}$ & Deutonura albella (Stach, 1920) * & - & - & - & - & 13 & - & 102 \\
\hline $\mathrm{E}$ & $\mathrm{e}$ & Deutonura conjuncta (Stach, 1926) & - & - & - & 13 & 4 & 25 & 4 \\
\hline $\mathrm{E}$ & $\mathrm{e}$ & Deutonura phlegraea (Caroli, 1912) & - & - & - & - & - & 4 & - \\
\hline $\mathrm{EN}, \mathrm{M}$ & $\mathrm{e}$ & Deutonura stachi (Gisin, 1952) * & - & - & 13 & - & - & - & - \\
\hline $\mathrm{H}, \mathrm{P}$ & $\mathrm{e}$ & Dicyrtoma fusca (Lubbock, 1873) & - & 4 & 47 & 8 & 4 & - & - \\
\hline $\mathrm{P}$ & $\mathrm{e}$ & Dicyrtomina minuta (Fabricius, 1783) & - & - & - & 8 & - & - & - \\
\hline $\mathrm{P}$ & $\mathrm{e}$ & Dicyrtomina ornata (Ncolet, 1842) & - & - & 30 & 4 & 13 & 4 & - \\
\hline $\mathrm{P}$ & $\mathrm{e}$ & Dicyrtomina violacea (Krausbauer, 1898) & - & - & - & - & - & 13 & - \\
\hline \multirow[t]{2}{*}{$\mathrm{E}, \mathrm{EN}$} & $\mathrm{e}$ & Endonura dudichi (Loksa, 1967) & - & - & 4 & 13 & 4 & 17 & 4 \\
\hline & & Entomobryidae juv. & 4 & 30 & 115 & 38 & 21 & 89 & 17 \\
\hline $\mathrm{E}$ & $\mathrm{e}$ & Entomobrya corticalis (Nicolet, 1842) & - & - & 8 & - & - & - & - \\
\hline $\mathrm{P}$ & $\mathrm{e}$ & Entomobrya marginata (Tullberg, 1871) & - & - & - & - & - & 8 & - \\
\hline $\mathrm{P}$ & $\mathrm{G}$ & Folsomia candida Willem, 1902 & - & - & 4 & - & - & - & - \\
\hline $\mathrm{M}$ & $\mathrm{e}$ & Folsomia inoculata Stach, 1947 * & - & - & - & - & 8 & - & - \\
\hline $\mathrm{P}$ & $\mathrm{G}$ & Folsomia kerni Gisin, 1948 & - & - & - & 13 & - & - & - \\
\hline $\mathrm{U}$ & $\mathrm{e}$ & Folsomia sp.* & 6183 & 3329 & 1660 & 841 & - & - & - \\
\hline $\mathrm{P}$ & $\mathrm{e}$ & Folsomia manolachei Bagnall, 1939 & - & - & - & - & 110 & 183 & 828 \\
\hline $\mathrm{H}$ & $\mathrm{e}$ & Folsomia penicula Bagnall, 1939 & - & - & 2972 & 55 & 268 & 3813 & 1711 \\
\hline $\mathrm{H}$ & $\mathrm{e}$ & Folsomia quadrioculata (Tullberg, 1871) & 55 & 8 & 17 & - & - & - & 255 \\
\hline $\mathrm{M}$ & $\mathrm{e}$ & Friesea albida Stach, 1949 * & 4 & 17 & 200 & 803 & 208 & 51 & 4 \\
\hline $\mathrm{C}$ & $\mathrm{e}$ & Friesea claviseta Axelson, 1900 & - & - & 4 & - & - & - & - \\
\hline $\mathrm{C}$ & $\mathrm{e}$ & Friesea mirabilis (Tullberg, 1871) & - & - & 4 & 13 & - & - & - \\
\hline $\mathrm{P}$ & $\mathrm{e}$ & Friesea truncata Cassagnau, 1958 & - & 4 & 17 & 127 & - & - & - \\
\hline $\mathrm{E}$ & $\mathrm{G}$ & Heteromurus nitidus (Templeton, 1835) & - & - & - & 8 & - & - & - \\
\hline \multirow[t]{2}{*}{$\mathrm{M}$} & $\mathrm{e}$ & Heteraphorura variotuberculata (Stach, 1934) * & 4 & - & 34 & 263 & 140 & 1520 & - \\
\hline & $\mathrm{e}$ & Hypogastrura sp. juv. & - & - & - & 4 & - & - & - \\
\hline $\mathrm{C}$ & $\mathrm{e}$ & Hypogastrura assimilis (Krausbauer, 1898) & 13 & 4 & - & - & - & - & - \\
\hline $\mathrm{P}$ & $\mathrm{e}$ & Choreutinula inermis (Tullberg, 1871) & - & - & - & 4 & - & - & - \\
\hline \multirow[t]{2}{*}{$\mathrm{C}$} & $\mathrm{e}$ & Isotomiella minor (Schäffer, 1896) & 4 & 34 & 72 & 722 & 624 & 1223 & 3096 \\
\hline & $\mathrm{e}$ & Isotoma sp. juv. & - & 187 & 59 & 106 & 13 & - & - \\
\hline $\mathrm{E}$ & $\mathrm{e}$ & Isotoma anglicana Lubbock, 1862 & - & - & 8 & - & - & - & - \\
\hline \multirow[t]{2}{*}{ M } & $\mathrm{G}$ & Kalaphorura carpenteri (Stach, 1919) * & - & 4 & - & - & 47 & 183 & - \\
\hline & $\mathrm{e}$ & Lepidocyrtus sp. juv. & 13 & - & - & - & - & - & - \\
\hline $\mathrm{U}$ & $\mathrm{e}$ & Lepidocyrtus sp. & 4 & 4 & 8 & 13 & 4 & - & - \\
\hline $\mathrm{W}$ & $\mathrm{e}$ & Lepidocyrtus cyaneus Tullberg, 1871 & - & 25 & 132 & 8 & - & - & - \\
\hline $\mathrm{E}$ & $\mathrm{e}$ & Lepidocyrtus lanuginosus (Gmelin, 1788) & - & - & - & - & 4 & - & 17 \\
\hline $\mathrm{W}$ & $\mathrm{e}$ & Lepidocyrtus lignorum (Fabricius, 1775) & 119 & 391 & 573 & 1698 & 1240 & 981 & 548 \\
\hline $\mathrm{SE}$ & $\mathrm{e}$ & Lepidocyrtus serbicus Denis, 1936 & 13 & 13 & 21 & 21 & 268 & 522 & 764 \\
\hline $\mathrm{BM}$ & $\mathrm{e}$ & Lepidocyrtus szeptyckii Rusek, 1985 * & - & - & - & - & 8 & 8 & - \\
\hline $\mathrm{H}$ & $\mathrm{e}$ & Lepidocyrtus violaceus (Fourcroy, 1785) & 30 & 4 & - & 8 & 4 & - & - \\
\hline $\mathrm{E}$ & $\mathrm{e}$ & Lipothrix lubbocki (Tullberg, 1872) & 4 & - & 4 & 8 & - & 624 & 221 \\
\hline $\mathrm{U}, \mathrm{EN}$ & $\mathrm{G}$ & Megalothorax carpaticus Papáč et Kováč, 2013 & - & 8 & - & - & - & - & - \\
\hline
\end{tabular}




\begin{tabular}{|c|c|c|c|c|c|c|c|c|c|}
\hline $\mathrm{C}$ & $\mathrm{G}$ & Megalothorax incertus Böner, 1903 & - & - & - & 4 & 13 & - & - \\
\hline $\mathrm{C}$ & $\mathrm{G}$ & Megalothorax minimus Willem, 1900 & - & 47 & 4 & 132 & 106 & 251 & 204 \\
\hline $\mathrm{H}$ & $\mathrm{G}$ & Mesaphorura critica Ellis, 1976 & - & - & - & 8 & 4 & - & - \\
\hline $\mathrm{P}$ & $\mathrm{G}$ & $\begin{array}{l}\text { Mesaphorura florae Simón, Ruiz, Martinez \& } \\
\text { Lucianez, } 1994\end{array}$ & - & - & - & 8 & - & - & - \\
\hline $\mathrm{P}$ & $\mathrm{G}$ & Mesaphorura italica (Rusek, 1971) & - & - & - & - & - & - & 13 \\
\hline $\mathrm{H}$ & $\mathrm{G}$ & Mesaphorura macrochaeta Rusek, 1976 & - & - & 4 & - & - & - & - \\
\hline $\mathrm{P}$ & $\mathrm{G}$ & Mesaphorura sylvatica (Rusek, 1971) & - & - & - & - & 13 & 8 & 13 \\
\hline $\mathrm{BM}$ & $\mathrm{e}$ & Micranurida granulata (Agrell, 1943) * & - & - & - & - & - & - & 4 \\
\hline $\mathrm{EN}, \mathrm{BM}$ & $\mathrm{e}$ & Micranurida vontoernei Nosek, 1962 * & - & - & - & 51 & 8 & 4 & 21 \\
\hline $\mathrm{H}$ & $\mathrm{e}$ & Micraphorura absoloni (Börner, 1901) & - & - & - & - & 4 & - & 8 \\
\hline $\mathrm{E}$ & $\mathrm{e}$ & Neanura parva (Stach, 1951) & - & - & - & - & - & 85 & 34 \\
\hline $\mathrm{E}$ & $\mathrm{e}$ & Neanura pseudoparva Rusek, 1963 & 4 & 13 & 55 & 64 & - & - & - \\
\hline \multirow[t]{2}{*}{$\mathrm{W}$} & $\mathrm{e}$ & Neonaphorura dungeri Schulz, 1994 & - & - & - & 4 & - & - & - \\
\hline & $\mathrm{u}$ & Onychiurus sp. juv. & - & - & 13 & - & - & - & - \\
\hline $\mathrm{E}$ & $\mathrm{e}$ & Onychiuroides pseudogranulosus (Gisin, 1951) & 4 & 81 & 144 & 943 & 306 & 42 & 4 \\
\hline $\mathrm{EN}, \mathrm{M}$ & $\mathrm{e}$ & Orthonychiurus rectopapillatus (Stach, 1933) * & - & - & - & 8 & - & - & - \\
\hline $\mathrm{E}$ & $\mathrm{G}$ & Oncopodura crassicornis Shoebotham, 1911 & - & - & 17 & 34 & 183 & 161 & - \\
\hline $\mathrm{E}$ & $\mathrm{e}$ & Orchesella bifasciata Nicolet, $1842^{\circ}$ & 4 & - & - & - & 4 & 21 & 8 \\
\hline $\mathrm{E}$ & $\mathrm{e}$ & Orchesella flavescens (Bourlet, 1843) & 13 & 55 & - & 4 & 4 & 21 & 21 \\
\hline $\mathrm{C}$ & $\mathrm{e}$ & Parisotoma notabilis (Schäffer, 1896) & 17 & 522 & 306 & 1635 & 628 & 883 & 2106 \\
\hline EN,M & $\mathrm{G}$ & Plutomurus carpaticus Rusek et Weiner, 1978 * & - & 68 & 586 & 603 & 38 & 64 & 34 \\
\hline \multirow[t]{2}{*}{$\mathrm{H}$} & $\mathrm{e}$ & Pogonognathellus flavescens (Tullberg, 1871) & - & 187 & 904 & 480 & 115 & 21 & 13 \\
\hline & $\mathrm{e}$ & Proisotoma sp. juv. & - & - & - & 4 & - & - & - \\
\hline $\mathrm{U}$ & $\mathrm{u}$ & Protaphorura sp. & - & 8 & - & - & - & - & - \\
\hline $\mathrm{W}$ & $\mathrm{G}$ & Protaphorura armata (Tullberg, 1869) * & 2420 & 2450 & 1469 & 1465 & 386 & 110 & 76 \\
\hline $\mathrm{W}$ & $\mathrm{e}$ & Protaphorura aurantiaca (Ridley, 1880) & 21 & 12365 & 1372 & 1261 & 985 & 2369 & 2429 \\
\hline $\mathrm{U}$ & $\mathrm{e}$ & Protaphorura cancellata (Gisin, 1956) & - & - & - & - & 30 & 13 & 21 \\
\hline $\mathrm{P}$ & $\mathrm{e}$ & Protaphorura campata (Gisin, 1952) & - & - & - & 127 & 399 & 119 & 4 \\
\hline $\mathrm{U}$ & $\mathrm{e}$ & Protaphorura gisini (Haybach, 1960) & - & - & - & - & 34 & 8 & 8 \\
\hline $\mathrm{U}$ & $\mathrm{e}$ & Protaphorura pannonica (Haybach, 1960) & 89 & 21 & - & 17 & - & - & - \\
\hline $\mathrm{U}$ & $\mathrm{e}$ & Protaphorura subarmata (Gisin, 1957) & - & 13 & 13 & 8 & 93 & 30 & 34 \\
\hline $\mathrm{U}$ & $\mathrm{e}$ & Protaphorura subuliginata (Gisin, 1956) & - & - & - & - & - & 13 & - \\
\hline $\mathrm{P}$ & $\mathrm{e}$ & Protaphorura tricampata (Gisin, 1956) & - & 34 & 17 & - & - & - & - \\
\hline $\mathrm{E}, \mathrm{P}$ & $\mathrm{e}$ & Pseudanurophorus boerneri Stach, 1922 & - & - & - & - & 4 & - & - \\
\hline $\mathrm{H}$ & $\mathrm{e}$ & Pseudachorutes corticicolus (Schäffer, 1896) & - & - & 4 & - & 13 & 13 & - \\
\hline $\mathrm{P}$ & $\mathrm{e}$ & Pseudachorutes dubius Krausbauer, 1898 & 13 & 8 & 25 & 55 & 8 & 13 & 4 \\
\hline $\mathrm{P}$ & $\mathrm{e}$ & Pseudachorutes parvulus Börner, $1901^{\circ}$ & - & - & - & - & 8 & 21 & 8 \\
\hline $\mathrm{SE}$ & $\mathrm{e}$ & Pseudachorutes palmiensis (Börner, 1903) & - & - & - & - & - & 4 & - \\
\hline $\mathrm{P}$ & $\mathrm{e}$ & Pseudachorutes subcrassus Tullberg, 1871 & - & - & 8 & 4 & - & - & 21 \\
\hline $\mathrm{C}$ & $\mathrm{e}$ & Pseudisotoma sensibilis (Tullberg, 1876) & 13 & 8 & - & - & 42 & - & - \\
\hline $\mathrm{U}$ & $\mathrm{e}$ & Pseudosinella sp. 1 & - & - & - & - & - & 4 & 8 \\
\hline $\mathrm{U}$ & $\mathrm{e}$ & Pseudosinella sp. 2 & - & - & - & - & - & 4 & - \\
\hline $\mathrm{U}$ & $\mathrm{e}$ & Pseudosinella albida (Stach, 1930) & - & - & 8 & 4 & - & - & - \\
\hline $\mathrm{E}$ & $\mathrm{e}$ & Pseudosinella horaki Rusek, 1985 & - & 55 & 195 & 607 & 1321 & 2577 & 2675 \\
\hline $\mathrm{U}$ & $\mathrm{G}$ & Pseudosinella thibaudi Stomp, 1977 & - & - & - & - & 4 & 25 & 8 \\
\hline $\mathrm{E}$ & $\mathrm{e}$ & Pseudosinella zygophora (Schille, 1908) & 8 & 8 & 17 & 8 & - & - & - \\
\hline E,EN & $\mathrm{e}$ & Pumilinura loksai (Dunger, 1973) & - & - & 47 & 21 & - & 25 & 17 \\
\hline $\mathrm{E}, \mathrm{EN}$ & $\mathrm{T}$ & Pygmarrhopalites aggtelekiensis Stach, 1945 & - & 30 & - & - & - & - & - \\
\hline $\mathrm{E}$ & $\mathrm{G}$ & Pygmarrhopalites bifidus Stach, 1945 & - & 4 & - & - & - & - & - \\
\hline $\mathrm{H}$ & $\mathrm{G}$ & Pygmarrhopalites pygmaeus (Wankel, 1860) & - & 98 & 13 & 8 & 13 & 59 & 4 \\
\hline $\mathrm{E}$ & $\mathrm{e}$ & Sminthurinus aureus (Lubbock, 1862) & - & 42 & 21 & 8 & 81 & 255 & 81 \\
\hline BM & $\mathrm{e}$ & Sminthurinus bimaculatus Axelson, 1902 * & - & - & - & - & 55 & 21 & - \\
\hline $\mathrm{W}$ & $\mathrm{e}$ & Sminthurinus elegans (Fitch, 1863) & - & - & - & - & 30 & 72 & 8 \\
\hline \multirow[t]{2}{*}{$\mathrm{M}$} & $\mathrm{e}$ & Sminthurinus gisini Gama, 1965 * & - & 4 & - & 4 & - & - & - \\
\hline & $\mathrm{e}$ & Sminthurus sp. juv. & - & - & - & - & - & 4 & 21 \\
\hline $\mathrm{SE}$ & $\mathrm{e}$ & Spathulosminthurus guthriei (Stach, 1920) & - & - & - & - & - & - & 4 \\
\hline $\mathrm{C}$ & $\mathrm{e}$ & Sphaeridia pumilis (Krausbauer, 1898) & - & - & - & 4 & 51 & 34 & 4 \\
\hline
\end{tabular}




\begin{tabular}{|c|c|c|c|c|c|c|c|c|c|}
\hline $\mathrm{P}, \mathrm{E}$ & $\mathrm{e}$ & Sphyrotheca multifasciata (Reuter, 1881) ${ }^{\mathrm{n}}$ & - & - & - & - & - & 4 & 4 \\
\hline $\mathrm{E}$ & $\mathrm{e}$ & Stenaphorurella lubbocki (Bagnall, 1935) & - & - & - & - & 4 & 8 & - \\
\hline $\mathrm{U}$ & $\mathrm{e}$ & Superodontella sp. 1 & - & - & - & - & - & 4 & 13 \\
\hline $\mathrm{U}$ & $\mathrm{e}$ & Superodontella sp. 2 & - & - & - & - & - & 4 & - \\
\hline EN,M & e & Superodontella tyverica Kaprus' et Weiner, 2009 n* & 4 & - & - & - & - & & - \\
\hline \multirow[t]{2}{*}{ EN,M } & $\mathrm{e}$ & Tetracanthella montana Stach, 1947 * & - & - & - & 4 & - & - & - \\
\hline & & Tomoceridae sp. juv. & - & - & 13 & 47 & 13 & 17 & - \\
\hline M & $\mathrm{e}$ & Tomocerus minor (Lubbock, 1802) * & 30 & - & - & - & - & - & - \\
\hline $\mathrm{H}$ & $\mathrm{e}$ & Tomocerus minutus Tullberg, 1876 & 4 & 47 & 110 & 611 & 459 & 369 & 115 \\
\hline $\mathrm{H}$ & $\mathrm{e}$ & Tomocerus vulgaris (Tullberg, 1871) & - & - & - & 72 & 30 & 72 & 127 \\
\hline M & $\mathrm{e}$ & Tetrodontophora bielanensis (Waga, 1842) * & 4 & - & 594 & 1397 & 187 & - & - \\
\hline $\mathrm{H}$ & $\mathrm{G}$ & Willemia anophthalma Börner, 1901 & 4 & - & - & - & - & - & - \\
\hline \multirow[t]{2}{*}{$\mathrm{E}$} & $\mathrm{G}$ & Willemia scandinavica Stach, 1949 & - & - & - & - & - & 4 & - \\
\hline & $\mathrm{e}$ & Vertagopus sp. juv & - & - & 4 & - & - & - & - \\
\hline $\mathrm{H}$ & $\mathrm{e}$ & Willowsia buski (Lubbock, 1869) & - & - & - & - & - & - & 8 \\
\hline $\mathrm{E}$ & $\mathrm{e}$ & Willowsia nigromaculata (Lubbock, 1873) & - & - & - & 4 & - & 4 & - \\
\hline $\mathrm{H}$ & $\mathrm{e}$ & Xenylla acauda Gisin, 1947 & 8 & - & 13 & - & - & - & - \\
\hline $\mathrm{E}$ & $\mathrm{e}$ & Xenylla brevisimilis Stach, 1949 & - & 4 & 8 & - & - & - & 4 \\
\hline $\mathrm{P}$ & $\mathrm{e}$ & Xenylla subacauda Stebaeva et Potapov, 1994 & 4 & - & - & - & - & - & - \\
\hline
\end{tabular}

n - first record from Slovakia, bold - new species for science, Ecological characteristics: e - edaphobiont, T - troglobiont, G - generalist, $\mathrm{u}$ - unknown, * - psychrophilic/cold-adapted species, ${ }^{\circ}-$ xeroresistant; Zoogeographical categories: EN - Carpathian/Western Carpathian endemic species, M - montane distribution, BM - boreo-montane distribution, E - European and Central European distribution, SE - South and Central European distribution, W - wide distribution including cosmopolitan, holarctic, palearctic (C, P, H); U - uncertain distribution (for site numbers see the Methods section). 